\title{
ESTUDO FLORÍSTICO DOS COMPONENTES ARBÓREO E ARBUSTIVO DA MATA DO PARQUE SANTO DIAS, SÃO PAULO, SP, BRASIL ${ }^{1}$
}

\author{
RICARDO JOSÉ FRANCISCHETTI GARCIA* \& JOSÉ RUBENS PIRANI**
}

\author{
* Prefeitura do Município de São Paulo - Departamento de Parques c Áreas Verdes - Herbário Municipal, Av. Pedro Álvares \\ Cabral s.n ${ }^{\circ}$ Pq. Ibirapucra - DEPAVE-4, 04094-050 - São Paulo, SP, Brasil \\ ** Departamento de Botânica, Instituto de Biociências, Universidade de São Paulo. Caixa Postal 11461, 05422-970 - São Paulo, \\ SP, Brasil
}

\begin{abstract}
Floristic study of the trecs and shrubs of the forcst of the Parque Santo Dias, São Paulo, SP, Brazil). A survey of the woody plants of the forest of the Parque Santo Dias, São Paulo, SP, Brazil is presented. The arca is a remnant of the native forest of the city, open to public visitation since 1992. Collections of botanical samples were made by the first author during 4 years (1992-1995), and specimens previously collected in the area were also available for the inventory. 154 species belonging to 110 genera in 55 families have been recognized. From these species, 1 is a trec-fern, 2 are gymnosperms, 146 are dicotyledons, and 5 are monocotyledons. The families with the greatest number of specics arc: Leguminosac (14 spp), Lauraceac, Myrtaccac and Solanaccac (12 spp cach), and Mclastomataccac and Rubiaceae (11 spp cach). Bascd on a floristic comparison with other forests in the State of São Paulo, it has been verified the predomination of elements from the Brazilian southern flora, and from montane mesophytic semideciduous forests. Also the occurrence of species with restricted distribution to the neighbourhoods are reported. Considerations on forest stratification and cvidences of human interference are pointed.
\end{abstract}

\begin{abstract}
Resumo - (Estudo floristico dos componentes arbóreo e arbustivo da mata do Parque Santo Dias, São Paulo, SP, Brasil). O presente trabalho consiste do levantamento das espécies dos componentes arbórco e arbustivo do Parque Santo Dias, área florestal remanescente no município de São Paulo, abcrta à visitação pública desde 1992. Foram coletados materiais férteis c estércis por período de quatro anos, que, somados aos colctados na década de 80 , resultaram $\mathrm{cm} 154$ espécies, pertencendo a 110 gêneros, de 55 famílias, sendo 1 espécie de pteridófita, 2 cspécies de gimnospermas, 146 cspćcies de dicotiledôncas c 5 espćcies de monocotiledôneas. As famílias com maior número de espécies são: Leguminosac (14), Lauraceac, Myrtaccac e Solanaccac (12 cada) c Rubiaccac e Mclastomataccae (11 cada). A partir de comparações floristicas com outras matas do cstado de São Paulo, verificou-se a predominância de elementos da flora do sul do país c das matas mesófilas semidecíduas de altitude, rcssaltando-se ainda a ocorrência de cspécies com distribuição restrita aos arredores da cidade. São feitas também consideraçōes sobre a fisionomia c cstratificação da mata e evidências da interferência antrópica.
\end{abstract}

Key words: floristics, São Paulo City, São Paulo Statc, Parque Santo Dias

\section{Introdução}

A vegetação florestal que ocorre no estado de São Paulo tem sido objeto de vários estudos florísticos e fitossociológicos, especialmente nos últimos dez anos, conforme se pode observar ao se comparar os levantamentos bibliográficos de Martins (1991), referente a dados obtidos até 1979, e Mantovani (1993). Contudo, a região do Planalto Atlântico, e em especial o Planalto Paulistano, são relativamente menos conhecidos do que a Depressão Periférica, apesar de ainda abrigarem grande parte dos remanescentes florestais do estado. O município de São Paulo, apesar de ter sofrido intensa transformação no uso do solo, ainda possui áreas com florestas nativas, especialmente concentradas na sua zona rural. Áreas com matas cercadas pela malha urbana são extremamente raras e, por isso mesmo, de fundamental importância para o conhecimento científico e conservação. Entre estas áreas destacam-se os parques públicos, como o Parque Santo Dias.

O presente trabalho teve como objetivos fornecer subsídios ao conhecimento da flora paulista e a estudos fitogeográficos, bem como ao manejo do Parque Santo Dias e de outros parques na região metropolitana de São Paulo.

\section{Materiais e Métodos}

Área de estudo - O Parque Santo Dias situa-se no município de São Paulo, nas coordenadas 2339'47"S e $46^{\circ} 46^{\prime} 21^{\prime \prime} \mathrm{W}$, sob clima temperado quente e úmido, segundo o sistema de Walter et al. (Rossi 1994). Possui $134.000 \mathrm{~m}^{2}$ dos quais $116.914 \mathrm{~m}^{2}$ são ocupados por mata e capoeiras, em altitudes entre 752 e $797 \mathrm{~m}$, apresentando em grande parte topografia com declives até maiores que $60 \%$, sobre solo de textura argilosa a argilo-arenosa (Prefeitura do Município de São Paulo 1994). A mata apresenta várias trilhas, algumas mantidas pelo projeto paisagístico (Takahashi et al. 1993), enquanto outras foram abertas espontaneamente pelos usuários do parque, apresentando graus variados de utilização e conservação (Fig. 1).

O Parque Santo Dias foi aberto à visitação pública em 1992, sendo administrado pelo Departamento de Parques e Áreas Verdes, da Prefeitura do Município de São Paulo, desde 1987. A mata foi conservada pelo Instituto Adventista de Ensino, entre 1915 a 1983. Em 1987, durante a construção de conjuntos habitacionais vizinhos, Takahashi et al. (1993) constataram que parte da mata foi desmatada, além de sofrer

' Parte da Dissertação de Mestrado do primciro autor, apresentada ao Instituto de Biociências da USP. 


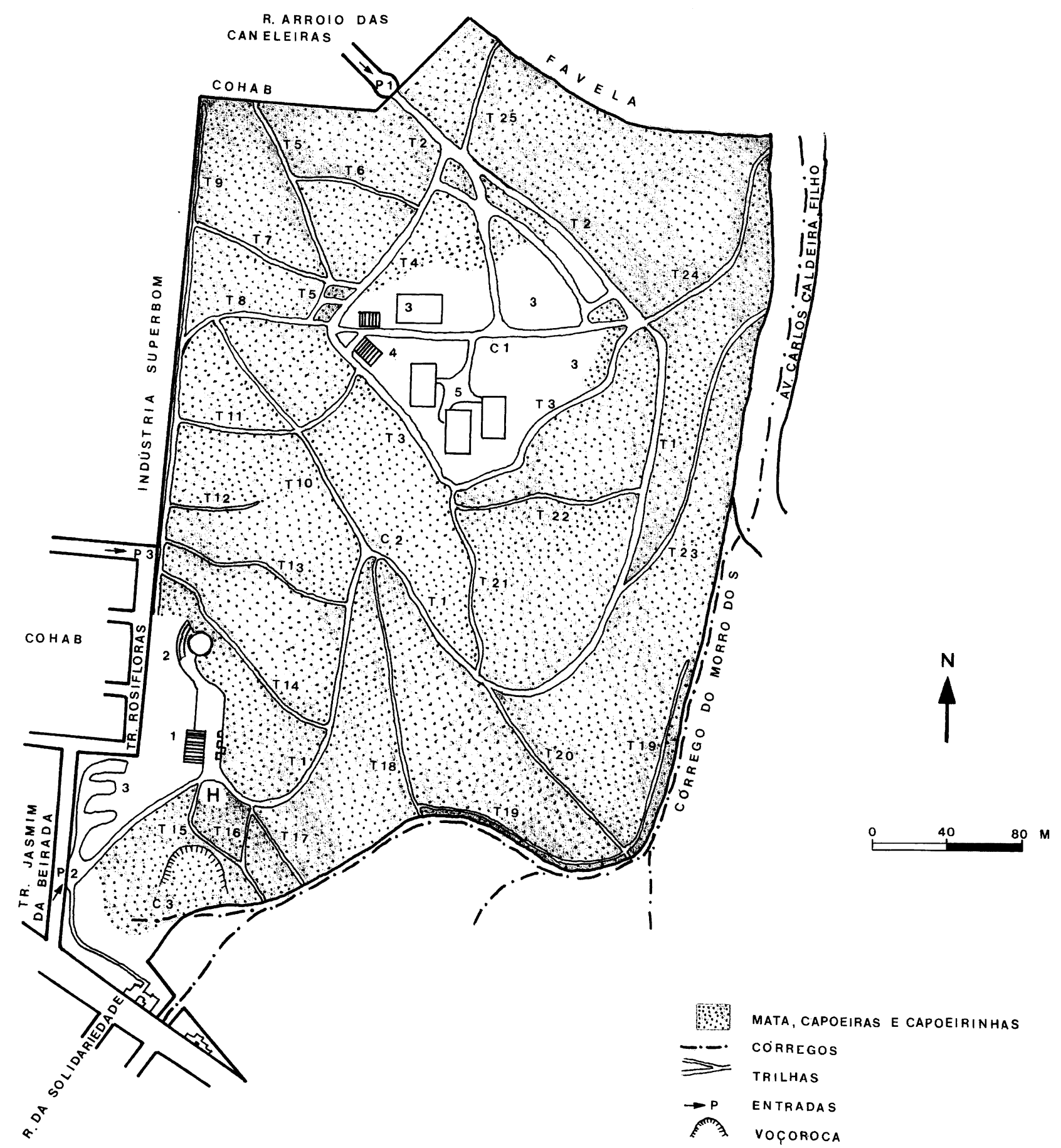

Fig. 1: Planta indicativa das trilhas (T1 a T25) no Parque Santo Dias, destacando-se: T1 - Trilha Principal e T2 - Trilha da Vochysia, acompanhando cota altitudinal de 770 m.s.m.; T10 -Trilha da Sálvia e T18 - Trilha do Samambaiaçu, formando linha de drenagem; T21 Trilha do Atalho, área onde se realizou o diagrama de perfil. 1 a 5: equipamentos do parque. 
danos ambientais como voçorocamento e poluição do solo. Trabalhos de manejo e educação ambiental vêm sendo realizados visando garantir a conservação da área (Garcia 1995).

Métodos - No período de março de 1992 a março de 1993, foram realizadas coletas em geral semanais, de modo que todo o parque pudesse ser percorrido no período de um mês. No período de abril a dezembro de 1993 as coletas foram mensais e em 1994 e 1995 foram esporádicas. Para a coleta de exemplares arbóreos utilizou-se tesoura de alta-poda com extensões encaixáveis que atingem até $12 \mathrm{~m}$ de altura. Quando isto não foi possível utilizou-se materiais caídos. A técnica de escalar árvores com cinto (peconha), foi utilizada complementarmente para algumas árvores, por Alexandre A. Oliveira. Os materiais foram herborizados segundo a técnica usual e, após o estudo, as exsicatas foram depositadas no herbário do Departamento de Botânica do Instituto de Biociências da Universidade de São Paulo (SPF), com duplicatas no herbário da Prefeitura do Município de São Paulo (PMSP).

Para a identificação dos materiais utilizou-se a bibliografia pertinente citada em Garcia (1995), acrescida de correções segundo Taylor e Lorence (1993) e Furlan (1996), a comparação com exsicatas depositadas em herbários, além da consulta a especialistas. Para a elaboração da chave utilizou-se predominantemente características vegetativas, denominadas conforme Radford et al. (1974), acompanhadas de desenhos de estruturas diagnósticas (Figuras 2-6), de forma a possibilitar sua utilização em campo.

O levantamento realizado, acrescido das espécies coletadas na década de 80 , permitiu indicar as famílias e gêneros com maior riqueza no parque e o número de espécies por família amostrada. A composição florística do parque foi comparada com a de outras áreas com matas estudadas no estado de São Paulo, com amostras das cinco feições geomorfológicas do estado (Almeida 1964, apud Mantovani 1993) e às quais estão associadas condições de clima, topografia e solo. Os trabalhos analisados passaram por uma prévia verificação de sinonímia das espécies, de acordo com a bibliografia consultada para identificação e foram agrupados por área de estudo, de forma que certas áreas apresentam um acúmulo de informações maior do que outras. Outros aspectos a serem ressalvados são: diferenças de metodologias empregadas, tamanho das áreas comparadas e dificuldade na identificação de espécies de famílias com muitos problemas taxonômicos. Utilizou-se o índice de similaridade de Sorensen (Mueller-Dombois \& Ellenberg 1974), para comparação com a Reserva da CUASO (São Paulo, SP), que apresenta tamanho e metodologia de coleta similares aos do Parque Santo Dias. Também foram comparados os números de espécies comuns de cada feição geomorfológica, agrupando-se as áreas analisadas. A distribuição geográfica foi obtida em bibliografia e em consultas a materiais dos herbários SP, SPF, SPSF, UEC e PMSP.

Foi elaborado um diagrama de perfil junto à Trilha do
Atalho, com área de $500 \mathrm{~m}^{2}$, com $50 \mathrm{~m}$ de compr. e $10 \mathrm{~m}$ de profundidade, para discussão da fisionomia da mata quanto à estratificação.

As espécies foram agrupadas segundo os padrões de dispersão de diásporos propostos por Pijl (1969), a partir de classificação dos diásporos observados e comparação com estudos similares (Kuhlmann \& Kühn 1947, Mantovani 1993 e Rossi 1994).

\section{Resultados e Discussão}

A partir do levantamento realizado, encontrou-se 154 espécies de plantas vasculares nos componentes arbóreo e arbustivo na mata do Parque Santo Dias, listadas na Tabela 1. As pteridófitas foram representadas por 1 espécie e as gimnospermas por 2 espécies, de famílias distintas. As dicotiledôneas apresentaram 146 espécies, pertencendo a 102 gêneros, de 50 famílias. As monocotiledôneas apresentaram 5 espécies, pertencendo a 5 gêneros, de 2 famílias.

\section{Chave para identificação das espécies}

1. Estipes (palmeiras) e fetos arborescentes (samambaiaçus)

2. Estipe entouceirado; acúleos com 0,5-6 cm compr. (Fig. 2A) Bactris setosa

2 '. Estipe único ou feto arborescente; acúleos, quando presentes, menores que $2 \mathrm{~mm}$ compr.

3. Folhas bipinadas (Fig. 2B), com soros na face abaxial (Fig. 2C), pecíolo com escamas (Fig. 2D) e acúleos (samambaiaçus)........ Cyathea delgadii

3'. Folhas pinadas, plantas com flores e frutos, inermes (palmeiras)

4. Folíolos regularmente distribuídos, no mesmo plano, discolores Lytocaryum hoehnei

4'. Folíolos irregularmente distribuídos, em vários planos, concolores.

1'. Árvores ou arbustos ou plantas bambusóides Syagrus romanzoffiana

5. Árvores caducifólias sem folhas presentes

6. Plantas em flor quando sem folhas

7. Corola tubulosa

8. Flores roxas........................................... Jacaranda puberula

8'. Flores amarelas ............................... Tabebuia chrysotricha

7'. Pétalas livres

9. Pétalas iguais, externamente negras Pseudobombax grandiflorum

9'. Vexilo falciforme cobrindo as demais pétalas, alaranjado Erythrina falcata

6'. Plantas em fruto quando sem folhas

10. Cápsula 5-valvar, com 5,5 cm compr. ............. Cedrela fissilis

10'. Cápsula 3-valvar, com $2 \mathrm{~cm}$ compr. .................. Qualea selloi

5'. Plantas perenifólias ou caducifólias com folhas presentes

11. Folhas compostas

12. Folhas digitadas

13. Folhas alternas

14. Estípulas intrapeciolares adnatas ao pecíolo (Fig. 2E-F); flores pequenas (ca. 0,2 cm compr.) em panículas de umbelas ............................ Didymopanax angustissimum

14'. Estípulas livres, caducas; flores grandes (ca. $10 \mathrm{~cm}$ compr.), isoladas ou em cimeiras bifloras

Pseudobombax grandiflorum 
13'. Folhas opostas

15. Folíolos com margem serreada e nervação semicraspedódroma (Fig. 2G); estípulas falciformes caducas (Fig. 2H) Lamanonia ternata

15'.Folíolos com margem inteira e nervação eucamptódroma; estípulas ausentes .......................... Tabebuia chrysotricha

12'. Folhas pinadas ou bipinadas

16. Folhas bipinadas

17. Folíolos elípticos a rombóides de margem serreada; pecíolos eglandulosos ............................... Jacaranda puberula

17' Folíolos oblongos a falciformes de margem inteira; peciolos com glândulas (Fig. 2I)

18. Plantas inermes Anadenanthera colubrina

18. Plantas armadas

19. Arbustos escandentes a lianas; acúleos nos ramos, pecíolos, raques foliares (Fig. 2I) e ramos das inflorescências Acacia plumosa

19'. Árvores; acúleos nos ramos e cristas do tronco Piptadenia gonoacantha

16'. Folhas pinadas

20. Folhas paripinadas ou falsamente paripinadas, pela presença de folíolos rudimentares no ápice da raque

21. Folhas paripinadas; pecíolos com pulvino

22. Folhas com até 12 folíolos

23. Folíolos com ápice mucronado e nervação broquidódroma ou mista

24. Raque não alada com uma glândula na inserção do par basal de folíolos Senna pendula

24'. Raque alada com glândulas na inserção de cada par de folíolos (Fig. 2J-K)

25. Folhas, raques, pecíolos e ramos tomentosos (Fig. 2K), com indumento ferrugíneo dourado ............ Inga sessilis

$25^{\prime}$. Folhas, raques, pecíolos e ramos glabros

Inga marginata

23'. Folíolos com ápice sem múcron e nervação eucamptódroma ou mista

26. Estípulas lineares, 4 folíolos, raque com glândulas na inserção dos folíolos ........................ Senna macranthera

26'. Estípulas foliáceas com 2 segmentos desiguais (Fig. 3A), 8 a 12 folíolos (Fig. 3B), raque sem glândulas.

22'. Folhas com mais de 20 folíolos Sclerolobium denudatum

27. Raque sem glândulas; folíolos oblongos, de ápice acuminado, 24 a 56 por folha .......... Cassia ferruginea

27'. Glândula na inserção do par basal de folíolos (Fig. 3C); folíolos elípticos a obovais, de ápice emarginadoapiculado (Fig. 3D), 26 a 30 por folha (Fig. 3E)........ Senna multijuga

21 '. Folhas falsamente paripinadas (Fig. 3F-G, I-J); pecíolos sem pulvino

28. Folhas com 16 ou mais folíolos, domácias nas axilas das nervuras secundárias, na face abaxial (Fig. $3 \mathrm{H}$ )

29. Folhas com 16 a 22 folíolos, nervação broquidódroma (Fig. 3F) Cabralea canjerana

29'. Folhas com 20 a 30 folíolos, nervação eucamptódroma Cedrela fissilis

28 . Folhas com até 12 folíolos, sem domácias

30. Folíolos com margem serreada na porção distal, ápice truncado a emarginado (Fig. 3J) ............Cupania oblongifolia

30'. Folíolos com margem inteira, ápice agudo a obtuso ........... Matayba guianensis
20'. Folhas imparipinadas ou trifolioladas

31. Folhas trifolioladas (Fig. 3K-L)

32. Pecíolo com pulvino, estipelas glanduliformes orbiculares (Fig. 3M) Erythrina falcata

32'. Pulvino, estípulas e estipelas ausentes (Fig. 3L)... Allophylus petiolulatus

31'. Folhas imparipinadas com 5 ou mais folíolos

33. Folhas opostas

34. Folhas com 5 foliolos, de margem inteira Platymiscium floribundum

34'. Folhas com 7 ou 9 foliolos, de margem serreada .. Sambucus australis

33'. Folhas alternas

35. Pecíolo com pulvino; folíolos com ápice obtuso, mucronado 36. Árvore; folhas com mais de 20 folíolos; estípulas podem estar modificadas em espinhos nos ramos mais velhos, estipelas ausentes .... Machaerium nyctitans

36'. Arbusto a arvoreta; folhas com menos de 20 folíolos; estípulas lineares, estipelas fimbriadas

Indigofera suffruticosa

35'. Pecíolo sem pulvino; folíolos com ápice agudo a acuminado, sem múcron

37. Raque foliar alada Schinus terebinthifolius

37 . Raque foliar não alada

38. Folíolos elípticos a lanceolados, com margem inteira Tapirira guianensis

38'. Folíolos rômbicos com margem parcialmente serreada, com dentes agudos (Fig. 4A) .......... Euplassa hoehnei

11'. Folhas simples

39. Plantas com presença de folhas opostas, verticiladas, subopostas ou subverticiladas

40. Plantas com apenas folhas opostas ou com apenas folhas verticiladas

41. Plantas exclusivamente com folhas verticiladas

42. Folhas com nervação broquidódroma; estípulas livres, triangulares ....................................... Vochysia magnifica

42'. Folhas com nervação eucamptódroma (Figura 4B); estípulas soldadas em tubo (Fig. 4C)

41'. Plantas exclusivamente com folhas opostas

43. Folhas com nervação acródroma (melastomatáceas)

44. Folhas glabras e lisas ao tato, ao menos na face adaxial; nervação basal ou suprabasal

45. Folhas concolores, verdes; margem inteira, ondulada a denticulada Miconia petropolitana

$45^{\prime}$. Folhas discolores, com face abaxial ferrugínea; margem inteira

46. Ápice das folhas obtuso-acuminado a arredondado; 5 nervuras suprabasais de mesmo calibre além de 1 par mais fino marginal .......................... Miconia cabussu

46'. Ápice das folhas agudo a caudado; 3 nervuras basais de mesmo calibre (Fig. 4D)

47. Folhas elípticas a ovais, de ápice caudado, $5-13 \mathrm{~cm}$ compr., sem nervuras marginais mais finas ....

Miconia cubatanensis

47'. Folhas elípticas, de ápice agudo, 11-19 cm compr., 1 par de nervuras mais finas marginais

Miconia eichleri

44'. Folhas com indumento estrigoso, setoso ou seríceo, ásperas ou macias ao tato; nervação suprabasal (Fig. 4E)

48. Folhas com 5 ou 7 nervuras de mesmo calibre, sem nervuras mais finas marginais 
49. Indumento avermelhado nos ramos novos, pecíolos e folhas; folhas com margem inteira, 5,5-11 cm compr.

50. Folhas elípticas, com relação comprimento/largura entre 2 e 2,5 ................................. Ossaea confertiflora

$50^{\prime}$. Folhas oval-lanceoladas, com relação comprimento/largura entre 3 e 3,6 ................. Ossaea amygdaloides

49'. Folhas com indumento concolor ou cinéreo, margem serreada a denticulada, $11-19 \mathrm{~cm}$ compr.

51. Folhas com ápice acuminado, margem denticulada, concolores com indumento estrigoso na face adaxial e tomentoso sobre as nervuras na face abaxial .......... Leandra dasytricha

51 '. Folhas com ápice agudo, margem serrilhada, discolores com indumento estrigoso na face adaxial e face abaxial alva, serícea a tomentosa Leandra sericea

48'. Folhas com 3 nervuras de mesmo calibre, com ou sem 1 par de nervuras mais finas marginais

52. Folhas com 11-16 cm compr. ..... Leandra melastomoides

52 '. Folhas com ate $8 \mathrm{~cm}$ compr.

53. Folhas com 5-8 cm compr. e 1,5-2 cm larg.; flores com ca. $9 \mathrm{~cm}$ diâm. .................... Tibouchina saldanhae

53'. Folhas com 3,5-8 cm compr. e 2-3 cm larg.; flores com ca. $5 \mathrm{~cm}$ diâm. ........................ Tibouchina sellowiana

43'. Folhas com outros padrões de nervação

54. Folhas sésseis de base auriculada e margem crenado-dentada nos $2 / 3$ superiores Buddleja brasiliensis

54 '. Folhas pecioladas, margem com outros padrões

55. Estípulas presentes, observáveis em ramos novos

56. Estípulas interpeciolares, não lineares (rubiáceas)

57. Ramos novos com 2 ou 4 espinhos (Fig. 4F) Randia armata

57'. Plantas inermes

58. Estípulas bífidas ou laceradas, unidas na base

59. Estípulas com lacínios largo-triangulares ou irregulares (Fig. 4G) ....................... Psychotria cephalantha

59'. Estípulas com lacínios triangulares ou linear-triangulares (Fig. 4H)

60. Folhas oval-lanceoladas, $11-20 \mathrm{~cm}$ compr. e $4-6 \mathrm{~cm}$ larg.; ramos das inflorescências vermelhos ou purpúreos ........................... Palicourea marcgravii

$60^{\prime}$. Folhas elípticas, estreito-elípticas, lanceoladas ou obovais, 4-12 cm compr. e 0,5-4 cm larg.; ramos das inflorescências verdes ou ferrugíneos

61. Folhas com nervação eucamptódroma, 8 a 10 pares de nervuras secundárias, ferrugíneas; estípulas com 5-10 mm compr. ........... Psychotria forsteronioides

61'. Folhas com nervação broquidódroma, 8 a 31 pares de nervuras secundárias, concolores; estípulas até $6 \mathrm{~mm}$ compr. Psychotria vellosiana

58 . Estípulas inteiras ou com ápice fimbriado

62. Estípulas de 0,5-1 cm compr., largo-ovais, ápice com fimbrias caducas .................... Rudgea jasminoides

62 . Estípulas até $5 \mathrm{~cm}$ compr., triangulares, com ápice agudo, inteiras

63. Folhas grandes (até $66 \mathrm{~cm}$ compr.), com nervuras tomentosas na face abaxial; estípulas com $5 \mathrm{~cm}$ compr. .............................. Bathysa meridionalis

63 '. Folhas menores (até $13 \mathrm{~cm}$ compr.), glabras; estípulas até $7 \mathrm{~mm}$ compr.

64. Árvores; folhas elípticas, oblongas ou obovais, de margem revoluta .................. Posoqueria latifolia
64'. Arbustos ou arvoretas; folhas elipticas, de margem plana

65. Folhas com 4 a 6 pares de nervuras secundárias; estípulas com $4 \mathrm{~mm}$ de compr.

Alibertia myrciifolia

$65^{\prime}$. Folhas com 8 a 12 pares de nervuras secundárias; estípulas com $1 \mathrm{~mm}$ compr. ... Psychotria suterella

56 '. Estípulas caducas não interpeciolares, ou reduzidas, ou glandulosas

66. Arvoretas ou arbustos escandentes com espinhos nas axilas foliares, especialmente as mais velhas; estípulas reduzidas a uma linha transversal ao caule (Fig. 4I) Strychnos brasiliensis

66'. Árvores inermes; estípulas com outros padrões

67. Estípulas pateliformes, ca. $1 \mathrm{~mm}$ diâm. (Fig. 4J); folhas discolores com margem revoluta; pecíolo uniforme ............................................ Qualea selloi

67'. Estípulas lineares caducas; folhas concolores com margem plana; pecíolo engrossado no ápice (Fig. 4K)

68. Folhas com 9-25 cm compr., margem repanda (Fig. 4L) ......................................... Sloanea guianensis

68'. Folhas com 3-16 cm compr., margem inteira (Fig. 4M) ou com poucos dentes no ápice

Sloanea monosperma

$55^{\prime}$. Estípulas ausentes

69. Árvores latescentes; ramos com cicatrizes anelares devido à união da base dos pecíolos ...... Peschiera australis

69'. Plantas sem látex

70. Acúleos nos ramos; margem foliar crenada

Lantana camara

70'. Plantas inermes; margem foliar inteira ou com dentes

71. Ramos e face abaxial das folhas com indumento ferrugíneo lanuginoso; folhas decussadas Aegiphila obducta

71 '. Sem o conjunto de caracteres

72. Margem foliar freqüentemente com dentes na metade apical; carpídios drupáceos

73. Árvores com casca profundamente fissurada; folhas com indumento flavescente, com 5,5-8 cm compr. Mollinedia triflora

73'. Arbustos ou arvoretas, casca não profundamente fissurada; folhas verdes, com mais de $9 \mathrm{~cm}$ compr. Mollinedia schottiana

72'. Margem foliar inteira; outros tipos de fruto

74. Ápice foliar emarginado a obtuso-acuminado com poro na face abaxial (Fig. 4N-O) ...... Lafoensia replicata

74 '. Ápice foliar agudo, acuminado, caudado ou arredondado, sem poro; folhas freqüentemente com glândulas translúcidas (mirtáceas)

75. Ápice foliar mucronado ..... Myrceugenia campestris

$75^{\prime}$. Ápice foliar sem múcron

76. Folhas novas unidas pela face adaxial, com face abaxial tomentosa e mais clara que as folhas velhas, 15 a 24 pares de nervuras secundárias, 10 $19 \mathrm{~cm}$ compr., 3,5-6,5 cm larg. ........................... Calyptranthes grandifolia

76'. Sem o conjunto de caracteres

77. Catafilos na base de ramos novos floríferos e frutíferos (Fig. 5A-B)

78. Catafilos com $1 \mathrm{~mm}$ compr.; folhas elípticas a obovais com ápice caudado ........ Eugenia excelsa 
78'. Catafilos com $5 \mathrm{~mm}$ compr.; folhas ovallanceoladas a elípticas, com ápice agudo ........

' Catafilos ausentes

79. Folhas elípticas a ovais, com ápice caudado, 4-8,5 cm compr.

80. Casca esfoliante, manchada; folhas glabras ........ Myrcia multiflora

$80^{\prime}$. Casca uniforme; folhas pubescentes Gomidesia tijucensis

79'. Sem o conjunto de caracteres

81. Nervação saliente na face adaxial das folhas

82. Folhas com glândulas translúcidas salientes na face adaxial; pecíolo com 3-5 mm compr. .......... Myrcia richardiana

82'. Glândulas não salientes; pecíolo com 10-20 mm compr. .............................. Myrcia pubipetala

81 '. Nervação não saliente na face adaxial das folhas

83. Casca esfoliante, internamente marrom avermelhada; folhas não buladas, onduladas Myrciaria floribunda

83'. Casca uniforme; folhas buladas, não onduladas

84. Folhas elípticas a obovais, $3,5-6,5 \mathrm{~cm}$ larg. ..... Gomidesia anacardiifolia

84'. Folhas lanceoladas (Fig. 5C) a oblongas, 1,5$2,5 \mathrm{~cm}$ larg. ........................ Plinia anonyma

40 '. Plantas com folhas alternas e subopostas, ou plantas com folhas alternas e subverticiladas, ou plantas com folhas opostas e subopostas, ou plantas com folhas opostas e subverticiladas

85. Plantas aculeadas

86. Arbustos; acúleos com 1-6 mm compr. nos ramos e folhas; folhas com margem inteira a 9-lobada, tomentosas, discolores .............................. Solanum aspero-lanatum

86'. Árvores; acúleos com $1 \mathrm{~mm}$ compr. na base de ramos novos; folhas com margem inteira, glabrescentes, concolores Solanum inaequale

85'. Plantas inermes

87. Folhas com margem serreada e nervação semicraspedódroma Eupatorium vauthierianum

87 . Folhas com margem inteira e nervação eucamptódroma, broquidódroma ou mista

88. Plantas com estípulas tomentoso-lanuginosas, estreitotriangulares Julocroton fuscescens

88'. Plantas sem estípulas

89. Ramos e pecíolos com tricomas longos ( $4 \mathrm{~mm}$ compr.), multicelulares (rajados a olho nu) ......... Athenea picta

$89^{\prime}$. Plantas glabras ou com outros tipos de indumento

90. Folhas discolores com face abaxial prateada; indumento lepidoto Solanum swartzianum

$90^{\prime}$. Folhas verdes ou com face abaxial ferrugínea; glabras ou com outros tipos de indumento

91. Arbustos até $40 \mathrm{~cm}$ alt.; folhas de 0,8-4,5 compr. Solanum pseudocapsicum

91'. Arvoretas ou árvores; folhas com 4-20 cm compr.

92. Folhas com domácias nas axilas das nervuras secundárias, na face abaxial ...... Chionanthus trichotomus

92'. Folhas sem domácias

93. Folhas glabras na face adaxial e ferrugíneotomentosas na face abaxial; nervuras terciárias paralelas entre si e perpendiculares à nervura primária Nectandra oppositifolia
93'. Sem o conjunto de caracteres

94. Folhas com pontuações ou glândulas translúcidas

95. Folhas elípticas, ápice agudo, nervação eucamptódroma ou mista, com 4 a 7 pares de nervuras secundárias ........................... Capsicum mirabile

95'. Folhas largo-elípticas (Fig. 5D) a obovais, ápice obtuso-acuminado, nervação broquidódroma, com 7 a 10 pares de nervuras secundárias ....... Eugenia cerasiflora

94'. Folhas sem pontuações ou glândulas translúcidas

96. Folhas amareladas quando secas, glabras; reticulação saliente na face abaxial ..... Ocotea odorifera

96'. Folhas negras quando secas (ao menos as mais novas), pubérulas sobre as nervuras; reticulação pouco ou não evidente

97. Folhas com 6-17 cm compr., 2,5-9,5 cm larg. e 7 a 11 pares de nervuras secundárias

Guapira nitida

97'. Folhas com 3-10 cm compr., 1,5-4 cm larg. e 4 a 8 pares de nervuras secundárias

Guapira opposita

39'. Plantas com presença exclusiva de folhas alternas

98. Folhas sésseis com nervação hifódroma (gimnospermas)

99. Copa umbeliforme com ramos maiores verticilados; ramos foliados caducos com crescimento contínuo; folhas com 0,5-2,5 cm compr. (Fig. 5E); escamas da gema terminal ausentes Araucaria angustifolia

99'. Copa irregular ou piramidal; ramos foliados com crescimento intermitente; folhas com 3-20 cm compr. (Fig. 5F) escamas da gema terminal lanceoladas (Fig. 5G) ...........

Podocarpus sellowi

98'. Folhas sésseis ou pecioladas, com outros tipos de nervação

100. Folhas com bainha ligulada (Fig. $5 \mathrm{H}$ ) e nervação paralelinérvia (gramíneas) (Fig. 5I)

101. Colmos maciços com râmulos verticilados Chusquea capituliflora

101 '. Colmos fistulosos com râmulos alternos

Lasiacis divaricata

100'. Folhas sem bainha, com outros tipos de nervação

102. Folhas com nervação actinódroma

103. Folhas grandes (até $55 \mathrm{~cm}$ compr.), palmatilobadas, peltadas (Fig. 5J)

104. Indumento estrigoso, ferrugíneo ...... Cecropia glazioui

104'. Indumento aracnóide, branco ........ Cecropia hololeuca

103'. Folhas menores (até $30 \mathrm{~cm}$ compr.), margem serreada a serrilhada; pecíolo basal

105. Folhas largo-elípticas a largo-ovais, com ápice obtusoacuminado e lâmina deflexa em relação ao pecíolo .... Alchornea sidifolia

105'. Sem o conjunto de caracteres

106. Arbustos; folhas ovais a elipticas, com indumento regularmente distribuído, eglandulares

Triumfetta semitriloba

106'. Árvores; folhas elípticas a lanceoladas (Fig. 5K) pubérulas sobre as nervuras, com 2 glândulas brilhantes próximas à base na face abaxial (Fig. 5L) ...... Alchornea triplinervia

102'. Folhas com outros tipos de nervação

107. Folhas com nervação semicraspedódroma

108. Plantas latescentes; folhas com margem serreadoaculeada, 7-12,5 cm compr. ....... Sorocea bonplandii

108'. Plantas sem látex, inermes; folhas com margem crenada, 
4-7 cm compr. Ilex amara

107'. Folhas com nervação broquidódroma, eucamptódroma ou mista

109. Plantas com estípulas

110. Plantas com látex

111. Folhas com nervação eucamptódroma, com $19-33 \mathrm{~cm}$ compr.; pecíolo torcido-costelado

Ecclinusa ramiflora

111'. Folhas com nervação broquidódroma, até $17,5 \mathrm{~cm}$ compr.; pecíolo não torcido

112. Folhas largo-elípticas a obovais, com 3-5 cm compr., 6 a 7 pares de nervuras secundárias

Ficus organensis

112 '. Folhas elípticas a oblongas, com mais de $8 \mathrm{~cm}$ compr., 7 a 19 pares de nervuras secundárias

113. Folhas com 7 a 11 pares de nervuras secundárias (Fig. 5M); estípula com ca. $1,5 \mathrm{~cm}$ compr. (Fig. $5 \mathrm{~N}$ ) .... Ficus luschnatiana

113'. Folhas com 12 a 19 pares de nervuras secundárias; estípula com 4,5-7 cm compr. .......... Ficus insipida

110'. Plantas sem látex

114. Folhas com margem serreada, serrilhada ou crenada

115. Folhas dísticas

116. Folhas escabras, base obtuso-truncada ou cordadoassimétrica Trema micrantha

116'. Folhas glabras ou pubescentes apenas sobre a nervura primária, na face abaxial, base cuneada

117. Ramos novos angulosos; pecíolos menores que $2 \mathrm{~mm}$ compr., até folhas sésseis; folhas sem pontuações translúcidas; pedicelos caducos

. Maytenus evonymoides

117'. Ramos novos não angulosos; pecíolos com 2-5 mm compr.; folhas com pontuações translúcidas; pedicelos articulados, com base persistente após frutificação (Fig. 5O) ............. Casearia sylvestris

115'. Folhas com filotaxia espiralada

118. Folhas com glândulas na base e na margem foliar (Fig. 5P, 6A-B) ..................... Xylosma glaberrimum

118'. Folhas com lâminas eglandulosas

119. Folhas glabras; pecíolos com 2 glândulas (Fig. 6CD); estípulas com $1 \mathrm{~mm}$ compr. Tetrorchidium rubrivenium

119 '. Folhas pubescentes; pecíolos eglandulosos; estípulas com 4-6 mm compr.

120. Folhas elípticas a oblongas, com 5 a 7 pares de nervuras secundárias .......... Pavonia schiedeana

$120^{\prime}$. Folhas ovais, com 4 a 5 pares de nervuras secundárias ........................................ Pavonia sepium

114 '. Folhas com margem inteira, plana, revoluta ou ondulada

121. Estípulas transformadas em espinhos ou calos; ápice foliar com múcron unguiculado (Fig. 6E-G) ...... Seguieria langsdorfii

121 '. Plantas inermes, sem o conjunto de caracteres

122. Estípulas transformadas em ócreas (Fig. 6H) . Coccoloba warmingii

122'. Estípulas não transformadas em ócreas

123. Estípulas persistentes nos ramos após a queda foliar (Fig. 6I)

124. Folhas obovais, ápice obtuso-arredondado mucronado Erythroxylum deciduum

124'. Folhas elípticas, ápice agudo a acuminado
.................................... Erythroxylum cuspidifolium

$123^{\prime}$. Estípulas caducas, às vezes observando-se apenas as cicatrizes

125. Folhas obovais a elípticas, ápice agudo a obtusoemarginado (Fig. 6J), com margem revoluta na base, formando domácias (Fig. 6K)

Pera glabrata

125'. Sem o conjunto de caracteres

126. Arbustos com ramos nodosos (piperáceas)

127. Folhas com 8 a 12 pares de nervuras secundárias Piper miquelianum

$127^{\prime}$. Folhas com 4 a 6 pares de nervuras secundárias

128. Base foliar obtusa a sub-truncada; estípulas com 1,5-2 cm compr.; pecíolo com 1,5-3 cm compr. Piper solmsianum

128'. Base foliar assimétrica (Fig. 6L); estípulas com 0,5 cm compr.; pecíolo com $0,1-0,3 \mathrm{~cm}$ compr. Piper gaudichaudianum

126'. Árvores ou arvoretas, nós dos ramos não salientes

129. Folhas discolores, pilosas

130. Folhas com indumento escamiforme; estípulas lineares, ca. $8 \mathrm{~mm}$ compr. .... Croton floribundus

130'. Folhas com pêlos simples; estípulas triangulares, ca. $3 \mathrm{~mm}$ compr. .......... Hirtella hebeclada

129'. Folhas concolores, glabras

131. Folhas com 2 glândulas na face abaxial, próximas à base (Fig. 6M-N), nervuras secundárias evidentes Prunus myrtifolia

131. Folhas eglandulosas; nervuras secundárias muito pouco nítidas Ouratea parviflora

109'. Plantas sem estípulas

132. Ápice foliar mucronado (Fig. 6O)

133. Folhas concolores, glabras, margem serrilhada com glândulas próximas à base ........... Sebastiania serrata

133'. Folhas discolores, pubescentes, tomentosas ou seríceas na face abaxial, margem não serrilhada

134. Folhas oval-lanceoladas a falciformes; pecíolo encurvado, com articulação nítida com o caule Cordia sellowiana

134'. Folhas elípticas, oblongas ou obovais; pecíolo reto, sem articulação nítida com o caule

135. Folhas com margem inteira; pecíolo cilíndrico, lanuginoso Vernonia diffusa

135'. Folhas com margem com dentes na metade apical; pecíolo canaliculado, engrossado na base, glabro Symplocos laxiflora

132'. Ápice das folhas sem múcron

136. Folhas sésseis a subsésseis (pecíolo com até $1 \mathrm{~mm}$ compr.); margem foliar freqüentemente com dentes

137. Folhas obovais a assimétricas (Fig. 6P), com margem parcialmente serrilhada e ápice seríceo na face abaxial (Fig. 6Q) Gordonia fruticosa

137 '. Folhas obovais a estreito-elípticas, com margem inteira ou com dentes na metade apical; indumento uniforme na face abaxial

Baccharis semiserrata

136'. Folhas nitidamente pecioladas, com margem inteira a sinuada

138. Folhas elípticas, 6 a 8 pares de nervuras secundárias, com domácias na face abaxial, 15,5-19,5 cm compr., 6,5-10,5 cm larg. Citronella megaphylla 
138'. Sem o conjunto de caracteres

139. Folhas disticas

140. Folhas com 15 a 25 pares de nervuras secundárias além de nervuras intersecundárias, salientes em ambas as faces; pecíolo ca. $10 \mathrm{~mm}$ compr.

Heisteria silvianii

140'. Folhas com 12 a 15 pares de nervuras secundárias; pecíolo com 2-4 mm compr. .... Guatteria australis

139'. Folhas com filotaxia espiralada

141. Acúleos nos ramos, folhas e pecíolos

Solanum variabile

141'. Plantas inermes

142. Folhas buladas, tomentoso-lanuginosas na face abaxial, 15,5-20 cm compr....... Solanum bullatum

142'. Sem o conjunto de caracteres

143. Ramos fistulosos, lenticelados; folhas com 17-24 cm compr., 7-11,5 cm larg.

Acnistus arborescens

143'. Sem o conjunto de caracteres

144. Folhas ovais a oval-lanceoladas, com ápice agudo ou obtuso

145. Folhas com base cordada, $2,5-8,5 \mathrm{~cm}$ larg. ........... Vernonia diffusa

145'. Folhas com base cuneada, arredondada ou assimétrica, 1,5-2,5 cm larg.

Piptocarpha oblonga

144 '. Folhas com outras formas; quando oval-lanceoladas, então ápice caudado

146. Folhas obovais, discolores, com pontuações translúcidas, 10 a 14 pares de nervuras secundárias Drimys brasiliensis

146'. Sem o conjunto de caracteres

147. Folhas com face abaxial tomentosa, hirsuta, lanuginosa ou vilosa

148. Face adaxial estrigosa ou tomentosa

149. Folhas com face adaxial estrigosa, verde; folhas axilares ausentes .... Vernonia polyanthes

149'. Folhas com face adaxial tomentosa, com tricomas estrelados, glauca; folhas axilares freqüentemente presentes (Fig. 6R-S) ..... ................... Solanum granuloso-leprosum

148'. Face adaxial glabra ou glabrescente

150. Folhas com face abaxial hirsuta; $3-5$ pares de nervuras secundárias

Endlicheria paniculata

$150^{\prime}$. Folhas com face abaxial tomentosa ou lanuginosa; 5-11 pares de nervuras secundárias

151. Folhas estreito-elípticas, margem revoluta, 0,8-1,7 cm larg.

Cinnamomum stenophyllum

151 '. Folhas elípticas a obovais, margem plana a ondulada, $2-5 \mathrm{~cm}$ larg.

152. Face abaxial tomentosa, com tricomas estrelados Piptocarpha axillaris

152'. Face abaxial lanuginosa ....... Ocotea lanata

147 '. Folhas glabras a glabrescentes na face abaxial

153. Arbustos a arvoretas com ramos decumbentes; folhas com pontuações translúcidas minúsculas; flores tubulosas, 1,5-2,5 cm compr.; cúpula ausente

154. Ramos novos com expansões aladas; folhas glanduloso-pubescentes; pecíolo com $0,5 \mathrm{~cm}$ compr

Brunfelsia pauciflora

154'. Ramos novos estriados; folhas glabras na face adaxial e glabrescentes na face abaxial; pecíolo com $0,5-1,5 \mathrm{~cm}$ compr.

Cestrum schlechtendalii

153'. Árvores ou arvoretas eretas; folhas com ou sem pontuaçōes translúcidas; flores com tépalas livres, até $3 \mathrm{~mm}$ compr.; bagas com cúpula (lauráceas)

155. Folhas glabras, ápice obtuso-acuminado; pecíolo 1-2,5 cm compr. ...... Aionea saligna

$155^{\prime}$. Folhas glabras a pubérulas, ápice arredondado, agudo, agudo-acuminado ou caudado; pecíolo até $1,5 \mathrm{~cm}$ compr.

156. Nervação eucamptódroma (Fig. 6T); axilas das nervuras secundárias com domácias na face abaxial (Fig. 6U)

Nectandra barbellata

156'. Nervação broquidódroma (Fig. 6V) ou mista

157. Nervuras secundárias salientes na face adaxial das folhas

158. Râmulos concentrados na região apical dos ramos, indicando crescimento intermitente; folhas com ápice agudo a agudo acuminado Ocotea elegans

158'. Râmulos dispostos em espaçamentos regulares nos ramos; folhas com ápice caudado Ocotea corymbosa

157'. Nervuras secundárias impressas na face adaxial

159. Ramos e pecíolos pubescentes ou tomentosos; folhas com ápice agudo-acuminado a arredondado, margem plana

Ocotea dispersa

159'. Ramos e pecíolos glabros ou glabrescentes; folhas com ápice agudo-acuminado a caudado (Fig. 6V) e margem revoluta

160. Folhas verde-oliváceas em ambas as faces no material seco, com nervação mista, 5 a 8 pares de nervuras secundárias, convexas na face adaxial; cúpula com margem 6-lobada Ocotea brachybotra

$160^{\prime}$. Folhas verde-azuladas na face adaxial e verde-amareladas na face abaxial, no material seco, com nervação broquidódroma, 4 a 6 pares de nervuras secundárias, côncavas na face adaxial; cúpula com margem simples Ocotea teleiandra

\section{Análise florística}

A riqueza em espécies de cada família amostrada está representada na Fig. 7, notando-se que 55,19\% das espécies fazem parte de Leguminosae (com 14 espécies), Lauraceae, Myrtaceae e Solanaceae (com 12 espécies cada uma), Rubiaceae e Melastomataceae (com 11 espécies cada uma), Euphorbiaceae (com 7 espécies) e Compositae (com 6 espécies). Estes dados se assemelham em parte aos obtidos para outras áreas estudadas no estado de São Paulo, ressaltando-se que: 
- enquanto para a Depressão Periférica até o Planalto Ocidental, Rutaceae e Meliaceae encontram-se entre as mais ricas em espécies, no Parque Santo Dias, como nas demais áreas comparadas do Planalto Atlântico e da Província Costeira tais famílias não apresentam a mesma riqueza. No parque, Meliaceae foi representada por 2 espécies, não se encontrando representantes nativos de Rutaceae.

- enquanto a Província Costeira apresentou grande riqueza em espécies para Sapotaceae e Chrysobalanaceae, o mesmo não ocorreu para as áreas do Planalto Atlântico e interior. No parque foram encontrados apenas 1 espécie de Chrysobalanaceae e 1 espécie de Sapotaceae.

- quando consideradas em conjunto, as 31 matas do estado comparadas (tabela 2) apresentaram maior riqueza em espécies para Myrtaceae, Leguminosae, Euphorbiaceae, Lauraceae, Rubiaceae e Meliaceae.

Foram encontradas no parque 30 famílias representadas por 1 espécie cada uma, totalizando $19,48 \%$ das espécies. Contudo, quando se considera a participação das famílias com apenas 1 espécie, estas representam $54,54 \%$ do total das famílias amostradas, valor acima do encontrado para a maioria das áreas comparadas.

Os gêneros que apresentaram maiores riquezas em espécies no parque foram: Ocotea (Lauraceae) e Solanum (Solanaceae) com 7 espécies cada; Psychotria (Rubiaceae) e Miconia (Melastomataceae) com 4 espécies cada; e Senna (Leguminosae-Caesalpinioideae), Leandra (Melastomataceae), Ficus (Moraceae), Eugenia e Myrcia (Myrtaceae) e Piper (Piperaceae) com 3 espécies cada. Ocotea, Eugenia, Ficus, Psychotria e Myrcia estão entre os 17 gêneros citados por Mantovani (1993) como os que apresentam maior riqueza nas florestas da encosta atlântica.
Aplicando-se o índice de similaridade de Sorensen, para comparar as matas do Parque Santo Dias e da Reserva da CUASO obteve-se $41,25 \%$ de similaridade, valor considerado baixo, indicando grande heterogeneidade florística para o Planalto Paulistano.

Analisando-se a distribuição geográfica conhecida das espécies do parque, são propostas as seguintes classes de distribuição:

1. espécies com distribuição ampla neotropical, ou pelo menos sul-americana, representando $22,73 \%$ do total de espécies do parque;

2. espécies com distribuição ampla no Brasil, da Amazônia até o Sul, ou do Nordeste até o Sul, ou do Centro-Oeste até o Sul, podendo atingir os países vizinhos da bacia do Paraná-Paraguai, ou da bacia Amazônica, com 22,07\% do total;

3. espécies com distribuição nas regiões Sul e Sudeste brasileiras (com pelo menos 1 estado além de SP), podendo atingir os países vizinhos da bacia do Paraná-Paraguai, com $39,61 \%$ do total;

4. espécies que têm SP como limite norte da distribuição, estendendo-se às vezes até a Argentina, com 3,90\% do total;

5. espécies que têm SP como limite sul da distribuição, estendendo-se às vezes até o Nordeste ou Centro-Oeste, com $9,74 \%$ do total;

6. espécies registradas apenas para SP, com $1,95 \%$ do total. Dentre estas, Lytocaryum hoehnei foi registrada pela primeira vez para o estado, em estudos florísticos e fitossociológicos.

Reunindo as categorias 1,2 e 3 , tem-se que $84,41 \%$ do total das espécies do Parque Santo Dias ocorrem em SP como parte de uma distribuição ampla por outros estados brasileiros, seja contínua ou descontínua. Reunindo as categorias 4 e 5 ,

Tabela 1. Lista de espécies amostradas no levantamento florístico da mata do Parque Santo Dias, São Paulo, SP. Hábito: arb - arbusto; arb.esc - arbusto escandente; árv - árvore; avt - arvoreta ( $<3 \mathrm{~m}$ alt.); avt.esc - arvoreta escandente; bam - planta bambusóide; est - estipe único; est.e - estipe entouceirado; feto - feto arborescente; hemi - hemi-epífita arbórea; sub - subarbusto. Tipo de dispersão dos diásporos: anemo - anemocoria; auto - autocoria; zoo - zoocoria; ? - não classificada. Distribuição geográfica: Br - Brasil; lim-N - limite norte em SP; lim-S - limite sul em SP; Neot - neotropical; r.SP - restrita a SP; S-SE - sul-sudeste. Número de coletor: os números referem-se a coletas de R.J.F.Garcia, depositadas no herbário SPF; outros coletores estão assinalados por letras remetendo a notas de rodapé.

\begin{tabular}{|c|c|c|c|c|}
\hline $\begin{array}{l}\text { DIVISÃO-CLASSE } \\
\text { Família } \\
\text { Espécie }\end{array}$ & hábito & $\begin{array}{l}\text { Tipo de dispersão } \\
\text { dos diásporos }\end{array}$ & $\begin{array}{l}\text { distribuição } \\
\text { geográfica }\end{array}$ & $\begin{array}{l}\text { número } \\
\text { do coletor }\end{array}$ \\
\hline \multicolumn{5}{|l|}{ PTEROPHYTA } \\
\hline Cyatheaceae & & & & \\
\hline $\begin{array}{l}\text { Cyathea delgadii Sternb. } \\
\text { PINOPHYTA }\end{array}$ & feto & Anemo & Neot & 424 \\
\hline Araucariaceae & & & & \\
\hline $\begin{array}{l}\text { Araucaria angustifolia (Bertol.) Kuntze } \\
\text { Podocarpaceae }\end{array}$ & árv & Zoo & S-SE & 78 \\
\hline Podocarpus sellowii Klotzsch ex Endl. & árv & Zoo & $\mathrm{Br}$ & $35, a^{2}$ \\
\hline
\end{tabular}

${ }^{z}$ L.Rossi et al. s.n. PMSP 511 
Tabela 1. Continuação

\begin{tabular}{|c|c|c|c|c|}
\hline $\begin{array}{l}\text { DIVISÃO-CLASSE } \\
\text { Família } \\
\quad \text { Espécie } \\
\end{array}$ & hábito & $\begin{array}{l}\text { Tipo de dispersão } \\
\text { dos diásporos }\end{array}$ & $\begin{array}{l}\text { distribuição } \\
\text { geográfica }\end{array}$ & $\begin{array}{l}\text { número } \\
\text { do coletor }\end{array}$ \\
\hline \multicolumn{5}{|l|}{ MAGNOLIOPHYTA - MAGNOLIOPSIDA } \\
\hline \multicolumn{5}{|l|}{ Anacardiaceae } \\
\hline Schinus terebinthifolius Raddi & árv & Zoo & $\mathrm{Br}$ & 260,370 \\
\hline Tapirira guianensis Aubl. & árv & Zoo & Neot & 193 \\
\hline \multicolumn{5}{|l|}{ Annonaceae } \\
\hline Guatteria australis A.St.-Hil. & árv & Zoo & S-SE & 263,331 \\
\hline \multicolumn{5}{|l|}{ Apocynaceae } \\
\hline \multicolumn{5}{|l|}{ Aquifoliaceae } \\
\hline Ilex amara (Vell.) Loes. & árv & Zoo & S-SE & 234,281 \\
\hline $\begin{array}{l}\text { Araliaceae } \\
\text { Didymopanax angustissimum Marchal }\end{array}$ & árv & Zoo & $\lim -\mathrm{S}$ & 413,434 \\
\hline $\begin{array}{l}\text { Jacaranda puberula Cham. } \\
\text { Tabebuia chrysotricha (Mart. ex A.DC.) Standl. } \\
\text { Bombacaceae }\end{array}$ & $\begin{array}{l}\text { árv } \\
\text { árv }\end{array}$ & $\begin{array}{l}\text { Anemo } \\
\text { Anemo }\end{array}$ & $\begin{array}{l}\mathrm{Br} \\
\mathrm{Br}\end{array}$ & $\begin{array}{l}179,317 \\
221,519\end{array}$ \\
\hline \multicolumn{5}{|l|}{ Boraginaceae } \\
\hline & \multicolumn{2}{|c|}{ Buddlejaceae } & & 349 \\
\hline $\begin{array}{l}\text { Buddleja brasiliensis Jacq. ex Spreng. } \\
\text { Caprifoliaceae }\end{array}$ & avt & Anemo & Neot & 422 \\
\hline $\begin{array}{l}\text { Sambucus australis Cham. \& Schltdl. } \\
\text { Cecropiaceae }\end{array}$ & arb-avt & Zoo & $\lim -\mathrm{N}$ & 251 \\
\hline Cecropia glazioui Snethl. & árv & Zoo & $\lim -\mathrm{S}$ & 105 \\
\hline C. hololeuca Miq. & árv & Zoo & $\mathrm{Br}$ & 54 \\
\hline \multicolumn{5}{|l|}{ Celastraceae } \\
\hline Maytenus evonymoides Reissek & árv & Zoo & $\mathrm{Br}$ & 108 \\
\hline \multicolumn{5}{|l|}{ Chrysobalanaceae } \\
\hline \multicolumn{4}{|l|}{ Compositae } & $b^{3}$ \\
\hline Baccharis semiserrata DC. & avt & Anemo & S-SE & 37,211 \\
\hline Eupatorium vauthierianum DC. & arb-avt & Anemo & S-SE & 83,92 \\
\hline Piptocarpha axillaris Baker & árv & Anemo & S-SE & 160 \\
\hline P. oblonga Baker & avt & Anemo & S-SE & 159 \\
\hline Vernonia diffusa Less. & árv & Anemo & S-SE & $158,242,256$ \\
\hline$V$. polyanthes Less. & arb-árv & Anemo & $\mathrm{Br}$ & $52,113,145$ \\
\hline \multicolumn{5}{|l|}{ Cunoniaceae } \\
\hline Lamanonia ternata Vell. & árv & Anemo & $\mathrm{Br}$ & 444 \\
\hline \multicolumn{5}{|l|}{ Elaeocarpaceae } \\
\hline Sloanea guianensis (Aubl.) Benth. & árv & Zoo & Neot & 338 \\
\hline S. monosperma Vell. & arb-árv & Zoo & S-SE & 10,373 \\
\hline \multicolumn{5}{|l|}{ Erythroxylaceae } \\
\hline Erythroxylum cuspidifolium Mart. & avt & Zoo & $\mathrm{Br}$ & 721 \\
\hline E. deciduum A.St.-Hil. & árv & Zoo & Neot & 157 \\
\hline \multicolumn{5}{|l|}{ Euphorbiaceae } \\
\hline Alchornea sidifolia (Spreng.) Müll. Arg. & árv & Zoo & S-SE & 46,55 \\
\hline A. triplinervia (Spreng.) Müll. Arg. & árv & Zoo & Neot & 337 \\
\hline Croton floribundus Spreng. & árv & Auto & $\lim -\mathrm{S}$ & 223 \\
\hline
\end{tabular}

${ }^{3}$ L. Rossi s.n. PMSP 456 
Tabela 1. Continuaçào

\begin{tabular}{|c|c|c|c|c|}
\hline $\begin{array}{l}\text { DIVISÃO-CLASSE } \\
\text { Família } \\
\quad \text { Espécie } \\
\end{array}$ & hábito & $\begin{array}{l}\text { Tipo de dispersão } \\
\text { dos diásporos }\end{array}$ & $\begin{array}{l}\text { distribuição } \\
\text { geográfica }\end{array}$ & $\begin{array}{l}\text { número } \\
\text { do coletor }\end{array}$ \\
\hline Julocroton fuscescens (Spreng.) Baill. & arb & Auto & $\mathrm{Br}$ & 132 \\
\hline Pera glabrata (Scott) Baill. & árv & Zoo & $\mathrm{Br}$ & $134,330,367$ \\
\hline Sebastiania serrata (Baill.) Müll. Arg. & árv & Auto & S-SE & 25,229 \\
\hline Tetrorchidium rubrivenium Poepp. \& Endl. & árv & Auto & Neot & 416 \\
\hline \multicolumn{5}{|l|}{ Flacourtiaceae } \\
\hline Casearia sylvestris $\mathrm{Sw}$. & árv & Zoo & Neot & 186,250 \\
\hline Xylosma glaberrimum Sleumer & árv & Zoo & S-SE & 421 \\
\hline \multicolumn{5}{|l|}{ Icacinaceae } \\
\hline $\begin{array}{l}\text { Citronella megaphylla (Mart.) R.A.Howard } \\
\text { Lauraceae }\end{array}$ & \multicolumn{3}{|c|}{ Lauraceae } & 722 \\
\hline Aiouea saligna Meisn. & árv & Zoo & $\mathrm{Br}$ & $181,219,228$ \\
\hline Cinnamomum stenophyllum (Meisn.) Kosterm. & árv & Zoo & S-SE & 387 \\
\hline Endlicheria paniculata (Spreng.) J.F.Macbr. & árv & Zoo & Neot & 106 \\
\hline Nectandra barbellata Coe-Teix. & árv & Zoo & lim-S & 231 \\
\hline N. oppositifolia Nees & árv & Zoo & Neot & 368 \\
\hline Ocotea brachybotra (Meisn.) Mez & árv & Zoo & S-SE & 364 \\
\hline O. corymbosa (Meisn.) Mez & avt & Zoo & $\lim -\mathrm{S}$ & 405 \\
\hline O. dispersa (Nees \& Mart. ex Nees) Mez & árv & Zoo & S-SE & 15,124 \\
\hline O. elegans Mez & árv & Zoo & S-SE & 6 \\
\hline O. lanata (Nees \& Mart. ex Nees) Mez & árv & Zoo & S-SE & 318 \\
\hline O. odorifera (Vell.) Rohwer & árv & Zoo & $\mathrm{Br}$ & $b^{4}$ \\
\hline O. teleiandra (Meisn.) Mez & árv & Zoo & S-SE & 98 \\
\hline \multicolumn{5}{|l|}{ Leguminosae-Caesalpinioideae } \\
\hline Cassia ferruginea (Schrad.) Schrad. ex DC. & árv & Zoo & S-SE & 122,300 \\
\hline Sclerolobium denudatum Vogel & árv & Anemo & $\lim -\mathrm{N}$ & $203,233,302$ \\
\hline Senna macranthera (Collad.) H.S.Irwin \& Barneby & árv & Zoo & $\mathrm{Br}$ & 326 \\
\hline S. multijuga (Rich.) H.S.Irwin \& Barneby & árv & Auto & Neot & 214,348 \\
\hline S. pendula (Willd.) H.S.Irwin \& Barneby & avt.esc & Auto & $\mathrm{Br}$ & 20 \\
\hline \multicolumn{5}{|l|}{ Leguminosae-Mimosoideae } \\
\hline Acacia plumosa Lowe & arb.esc & Auto & $\lim -\mathrm{N}$ & 365 \\
\hline Anadenanthera colubrina (Vell.) Brenan & árv & Anemo & $\mathrm{Br}$ & 148,427 \\
\hline Inga marginata Willd. & avt & Zoo & Neot & 717 \\
\hline I. sessilis (Vell.) Mart. & árv & Zoo & S-SE & 378 \\
\hline Piptadenia gonoacantha (Mart.) J.F.Macbr. & árv & Anemo & $\mathrm{Br}$ & 4,517 \\
\hline \multicolumn{5}{|l|}{ Leguminosae-Papilionoideae } \\
\hline Erythrina falcata Benth. & árv & Auto & Neot & 514 \\
\hline Indigofera suffruticosa Mill. & arb-avt & Auto & Neot & 369 \\
\hline Machaerium nyctitans Benth. & árv & Anemo & $\lim -\mathrm{S}$ & 152,322 \\
\hline Platymiscium floribundum Vogel & árv & Anemo & S-SE & 258,211 \\
\hline \multicolumn{5}{|l|}{ Loganiaceae } \\
\hline Strychnos brasiliensis (Spreng.) Mart. & avt & Zoo & S-SE & 428 \\
\hline \multicolumn{5}{|l|}{ Lythraceae } \\
\hline Lafoensia replicata Pohl & árv & Anemo & $\lim -\mathrm{S}$ & 295 \\
\hline \multicolumn{5}{|l|}{ Malvaceae } \\
\hline Pavonia schiedeana Steud. & arb & Zoo & Neot & 81 \\
\hline P. sepium A.St.-Hil. & arb & Zoo & Neot & 355 \\
\hline \multicolumn{5}{|l|}{ Melastomataceae } \\
\hline Leandra dasytricha (A.Gray) Cogn. & arb-avt & Zoo & S-SE & 13,226 \\
\hline L. melastomoides Raddi & arb-avt & Zoo & $\mathrm{Br}$ & 16,285 \\
\hline
\end{tabular}

${ }^{4}$ L.Rossi et al. s.n. PMSP 247 
Tabela 1. Continuação

\begin{tabular}{|c|c|c|c|c|}
\hline $\begin{array}{l}\text { DIVISÃO-CLASSE } \\
\text { Família } \\
\text { Espécie } \\
\end{array}$ & hábito & $\begin{array}{l}\text { Tipo de dispersão } \\
\text { dos diásporos }\end{array}$ & $\begin{array}{l}\text { distribuição } \\
\text { geográfica }\end{array}$ & $\begin{array}{l}\text { número } \\
\text { do coletor }\end{array}$ \\
\hline L. sericea $\mathrm{DC}$. & arb & Zoo & $\lim -S$ & 288 \\
\hline Miconia cabussu Hoehne & árv & Zoo & $\lim -S$ & 261 \\
\hline M. cubatanensis Hoehne & avt-árv & Zoo & S-SE & 127,404 \\
\hline M. eichleri Cogn. & árv & Zoo & S-SE & $19, c^{5}$ \\
\hline M. petropolitana Cogn. & arb-avt & Zoo & S-SE & 180 \\
\hline Ossaea amygdaloides (DC.) Triana & arb & Zoo & S-SE & 380 \\
\hline O. confertiflora (DC.) Triana & arb & Zoo & $\mathrm{Br}$ & 246 \\
\hline Tibouchina saldanhae Cogn. & árv & Anemo & $\lim -\mathrm{S}$ & 253 \\
\hline T. sellowiana (Cham.) Cogn. & arb-avt & Anemo & S-SE & 43 \\
\hline \multicolumn{5}{|l|}{ Meliaceae } \\
\hline Cabralea canjerana (Vell.) Mart. & árv & Zoo & Neot & 244 \\
\hline Cedrela fissilis Vell. & árv & Anemo & Neot & 96,426 \\
\hline \multicolumn{5}{|l|}{ Monimiaceae } \\
\hline Mollinedia schottiana (Spreng.) Perkins & arb-avt & Zoo & $\mathrm{Br}$ & 103 \\
\hline M. triflora (Spreng.) Tul. & árv & Zoo & S-SE & 185 \\
\hline \multicolumn{5}{|l|}{ Moraceae } \\
\hline Ficus insipida Willd. & árv & Zoo & Neot & 442 \\
\hline F. luschnatiana (Miq.) Miq. & hem & Zoo & S-SE & 208 \\
\hline F. organensis (Miq.) Miq. & árv & Zoo & S-SE & 217 \\
\hline Sorocea bonplandii (Baill.) W.C.Burger, Lanj. \& de Boer & árv & Zoo & S-SE & 268 \\
\hline \multicolumn{5}{|l|}{ Myrtaceae } \\
\hline Calyptranthes grandifolia O.Berg & árv & Zoo & S-SE & 66,321 \\
\hline Eugenia cerasiflora Miq. & árv & Zoo & $\mathrm{Br}$ & 118 \\
\hline E. excelsa O.Berg & árv & Zoo & S-SE & 194,224 \\
\hline E. uniflora $\mathrm{L}$. & árv & Zoo & S-SE & 199 \\
\hline Gomidesia anacardiifolia (Gardner) O.Berg & arb-árv & Zoo & S-SE & 5,303 \\
\hline G. tijucensis (Kiaersk.) D.Legrand & árv & Zoo & S-SE & 323,346 \\
\hline Myrceugenia campestris (DC.) D.Legrand \& Kausel & arb & Zoo & S-SE & 412 \\
\hline Myrcia multiflora (Lam.) DC. & árv & Zoo & $\mathrm{Br}$ & 227 \\
\hline M. pubipetala Miq. & avt-árv & Zoo & S-SE & $d^{6}, e^{7}$ \\
\hline M. richardiana O.Berg & árv & Zoo & S-SE & $\mathrm{f}^{8}$ \\
\hline Myrciaria floribunda (West ex Willd.) O.Berg & árv & Zoo & Neot & 328 \\
\hline Plinia anonyma Sobral & avt & Zoo & $\lim -\mathrm{S}$ & 171 \\
\hline \multicolumn{5}{|l|}{ Nyctaginaceae } \\
\hline Guapira nitida (Mart. ex J.A.Schmidt) Lundell & avt & Zoo & $\lim -\mathrm{S}$ & 430 \\
\hline G. opposita (Vell.) Reitz & árv & Zoo & $\mathrm{Br}$ & 236,254 \\
\hline \multicolumn{5}{|l|}{ Ochnaceae } \\
\hline Ouratea parviflora (DC.) Baill. & arb-avt & Zoo & $\lim -\mathrm{N}$ & 49 \\
\hline \multicolumn{5}{|l|}{ Olacaceae } \\
\hline Heisteria silvianii Schwacke & árv & Zoo & S-SE & 437,720 \\
\hline \multicolumn{5}{|l|}{ Oleaceae } \\
\hline Chionanthus trichotomus (Vell.) P.S.Green & árv & Zoo & $\mathrm{Br}$ & 163 \\
\hline \multicolumn{5}{|l|}{ Phytolaccaceae } \\
\hline Seguieria langsdorfii Moq. & árv & Anemo & $\mathrm{Br}$ & 133,209 \\
\hline \multicolumn{5}{|l|}{ Piperaceae } \\
\hline Piper gaudichaudianum Kunth & arb & Zoo & $\mathrm{Br}$ & 93 \\
\hline P. miquelianum C.DC. & arb & Zoo & $\mathrm{Br}$ & 48 \\
\hline P. solmsianum C.DC. & arb & Zoo & S-SE & 32 \\
\hline
\end{tabular}

${ }^{5}$ L.Rossi \& R.J.F.Garcia s.n. PMSP 549

${ }^{7}$ L.Rossi et al. s.n. PMSP 596

${ }^{6}$ L.Rossi \& R.J.F.Garcia s.n. PMSP 555

${ }^{8}$ R.J.F.Garcia et al. s.n. PMSP 541 
Tabela 1. Continuação

\begin{tabular}{|c|c|c|c|c|}
\hline $\begin{array}{l}\text { DIVISÃO-CLASSE } \\
\text { Família } \\
\quad \text { Espécie } \\
\end{array}$ & hábito & $\begin{array}{l}\text { Tipo de dispersão } \\
\text { dos diásporos }\end{array}$ & $\begin{array}{c}\text { distribuição } \\
\text { geográfica }\end{array}$ & $\begin{array}{l}\text { número } \\
\text { do coletor }\end{array}$ \\
\hline \multicolumn{5}{|l|}{ Polygonaceae } \\
\hline Coccoloba warmingii Meisn. & árv & Zoo & S-SE & 374 \\
\hline \multicolumn{5}{|l|}{ Proteaceae } \\
\hline Euplassa hoehnei Sleumer & árv & Zoo & r.SP & 423 \\
\hline \multicolumn{5}{|l|}{ Rosaceae } \\
\hline Prunus myrtifolia (L.) Urban & árv & Zoo & $\mathrm{Br}$ & 324 \\
\hline \multicolumn{5}{|l|}{ Rubiaceae } \\
\hline Alibertia myrciifolia K.Schum. & avt & Zoo & Neot & 385 \\
\hline Amaioua intermedia Mart. & árv & Zoo & S-SE & 279 \\
\hline Bathysa meridionalis L.B.Sm. \& Downs & árv & Anemo & S-SE & 350 \\
\hline Palicourea marcgravii A.St.-Hil. & arb & Zoo & Neot & 50,273 \\
\hline Posoqueria latifolia (Rudge) Roem. \& Schult. & árv & Zoo & Neot & 375 \\
\hline Psychotria cephalantha (Müll. Arg.) Standl. & avt & Zoo & Neot & 435 \\
\hline P. forsteronioides Müll. Arg. & sub-avt & Zoo & S-SE & 306 \\
\hline P. suterella Müll. Arg & arb-avt & Zoo & S-SE & 1,65 \\
\hline P.vellosiana Benth. & arb-avt & Zoo & Neot & 97,275 \\
\hline Randia armata (Sw.) DC. & árv & Zoo & Neot & 516 \\
\hline Rudgea jasminoides (Cham.) Müll. Arg. & arb-avt & Zoo & $\lim -\mathrm{N}$ & 12,101 \\
\hline \multicolumn{5}{|l|}{ Sapindaceae } \\
\hline Allophylus petiolulatus Radlk. & arb-avt & Zoo & S-SE & 73 \\
\hline Cupania oblongifolia Mart. & árv & Zoo & S-SE & 22,237 \\
\hline Matayba guianensis Aubl. & árv & Zoo & Neot & 425 \\
\hline \multicolumn{5}{|l|}{ Sapotaceae } \\
\hline Ecclinusa ramiflora Mart. & árv & Zoo & Neot & 417 \\
\hline \multicolumn{5}{|l|}{ Solanaceae } \\
\hline Acnistus arborescens (L.) Schltdl. & árv & Zoo & Neot & 184 \\
\hline Athenea picta (Mart.) Sendtn. & avt & Zoo & S-SE & $\mathrm{h}^{9}$ \\
\hline Brunfelsia pauciflora (Cham. \& Schltdl.) Benth. & arb & Zoo & $\lim -\mathrm{N}$ & 166 \\
\hline Capsicum mirabile Mart. ex Sendtn. & árv & Zoo & S-SE & 266 \\
\hline Cestrum schlechtendalii G.Don & arb-avt & Zoo & $\lim -\mathrm{S}$ & 63,104 \\
\hline Solanum aspero-lanatum Ruiz \& Pav. & arb & Zoo & $\mathrm{Br}$ & 146 \\
\hline S. bullatum Vell. & árv & Zoo & S-SE & $\mathrm{i}^{10}$ \\
\hline S. granuloso-leprosum Dunal & árv & Zoo & S-SE & 8,238 \\
\hline S. inaequale Vell. & árv & Zoo & S-SE & $202, j^{11}$ \\
\hline S. pseudocapsicum $\mathrm{L}$. & arb & Zoo & Neot & 419 \\
\hline S. swartzianum Roem. \& Schult. & arb-avt & Zoo & S-SE & 11 \\
\hline S. variabile Mart. & arb-avt & Zoo & S-SE & 42 \\
\hline \multicolumn{5}{|l|}{ Symplocaceae } \\
\hline Symplocos laxiflora Benth. & árv & Zoo & $\mathrm{Br}$ & 719 \\
\hline \multicolumn{5}{|l|}{ Theaceae } \\
\hline Gordonia fruticosa (Schrad.) H.King & árv & Anemo & Neot & 272 \\
\hline \multicolumn{5}{|l|}{ Tiliaceae } \\
\hline Triumfetta semitriloba Jacq. & arb & Zoo & Neot & 2 \\
\hline \multicolumn{5}{|l|}{ Ulmaceae } \\
\hline Trema micrantha Blume & árv & Zoo & Neot & 7 \\
\hline \multicolumn{5}{|l|}{ Verbenaceae } \\
\hline Aegiphila obducta Vell. & arb.esc & Zoo & $\lim -\mathrm{S}$ & 51 \\
\hline Lantana camara $\mathrm{L}$. & avt & Zoo & Neot & 138 \\
\hline
\end{tabular}

9 L.Rossi et al. s.n. PMSP 244

" L.Rossi \& R.J.F.Garcia s.n. PMSP 558

${ }^{10}$ L.Rossi et al. s.n. PMSP 453 
Tabela 1. Continuação

\begin{tabular}{|c|c|c|c|c|}
\hline $\begin{array}{l}\text { DIVISÃO-CLASSE } \\
\text { Família } \\
\quad \text { Espécie } \\
\end{array}$ & hábito & $\begin{array}{l}\text { Tipo de dispersão } \\
\text { dos diásporos }\end{array}$ & $\begin{array}{l}\text { distribuição } \\
\text { geográfica }\end{array}$ & $\begin{array}{l}\text { número } \\
\text { do coletor }\end{array}$ \\
\hline \multicolumn{5}{|l|}{ Vochysiaceae } \\
\hline Qualea selloi Warm. & árv & Anemo & r.SP & 47,299 \\
\hline Vochysia magnifica Warm. & árv & Anemo & S-SE & 28,174 \\
\hline \multicolumn{5}{|l|}{ Winteraceae } \\
\hline Drimys brasiliensis Miers & árv & Zoo & $\mathrm{Br}$ & 267 \\
\hline \multicolumn{5}{|l|}{ MAGNOLIOPHYTA - LILIOPSIDA } \\
\hline \multicolumn{5}{|l|}{ Gramineae } \\
\hline Chusquea capituliflora Trin. & bam & $?$ & S-SE & 69 \\
\hline Lasiacis divaricata (L.) Hitchc. & bam & $?$ & Neot & 135 \\
\hline \multicolumn{5}{|l|}{ Palmae } \\
\hline Bactris setosa Mart. & est.e & Zoo & S-SE & 377 \\
\hline Lytocaryum hoehnei (Burret) Toledo & est & Zoo & r.SP & 30 \\
\hline Syagrus romanzoffiana (Cham.) Glassman & est & Zoo & $\mathrm{Br}$ & 511 \\
\hline
\end{tabular}

tem-se que $13,64 \%$ do total das espécies do parque têm SP como limite norte ou sul de sua distribuição.

As categorias 5 e 6 são importantes para particularizar a flora local. Deve ser ressalvado, no entanto, que pode ter havido uma representação maior do que a real, devido a possíveis falhas na pesquisa bibliográfica, ou mesmo pela falta de coletas ou ainda identificações incompletas ou incorretas, que podem acarretar ausência de registro destas espécies para outros estados.

Quanto às espécies que tiveram limite de distribuição sul em SP pode-se sugerir como fator ecológico importante a ocorrência generalizada de geadas em SP, enquanto em estados vizinhos ao norte o fenômeno é menos intenso ou espacialmente restrito (Silva \& Shepherd 1986), ou mesmo devido a temperaturas mais frias, como sugerido para explicar o limite de distribuição de espécies de matas mesófilas semidecíduas, por Oliveira Filho \& Ratter (1995). Contudo, também parece clara a interferência de fatores históricos nesta distribuição, pelo menos para as espécies com ocorrência registrada para $\mathrm{SP}$ e as serras de MG e RJ, também sujeitas a geadas, o que poderia sugerir uma ligação pretérita entre as floras do Planalto Paulistano e a Serra dos Órgãos, interrompida em graus variados, durante flutuações climáticas do Quaternário. As montanhas apresentam condições ambientais diversificadas de solos, exposição ao sol, pluviosidade e temperatura atmosféricas variáveis com a altitude e latitude; têm sido por isso consideradas como espaços adequados para a manutenção de espécies em "refúgios", durante períodos geológicos com climas desfavoráveis a uma distribuição mais ampla (Veloso et al. 1991; Oliveira Filho \& Ratter 1995). Quando as condições climáticas mudam para uma situação favorável à expansão das espécies a partir dos "refúgios", o tempo decorrido pode ter sido suficiente para a sua modificação em novas espécies. Neste sentido observou-se que:
- Euplassa hoehnei (Proteaceae) apresentou ocorrência registrada para o Parque do Estado e Campos do Jordão, tendo o material do Parque Santo Dias caracteres próximos a E. taubertiana e E. itatiaiae, descritas para o Pq. Nacional de Itatiaia (RJ).

- Tibouchina saldanhae (Melastomataceae) e Plinia anonyma (Myrtaceae) foram assinaladas em SP apenas para o Parque Santo Dias, e no RJ para a Serra dos Órgãos, não sendo registradas na Serra da Mantiqueira, ressaltandose que o DAP de indivíduos adultos destas espécies teriam permitido sua inclusão em estudos fitossociológicos já realizados, nos quais, contudo, não foram registrados.

- Aegiphila obducta (Verbenaceae) foi encontrada também na Ilha do Cardoso (SP), na Serra da Mantiqueira, serras de MG e Serra dos Órgãos (RJ).

- Lytocaryum hoehnei (Palmae) apresenta distribuição restrita aos arredores da cidade de São Paulo, sendo o gênero composto por mais 1 espécie com ocorrência restrita às serras do RJ e ES (Henderson et al.1995).

- na análise de similaridade florística realizada para as matas brasileiras, baseada em gêneros arbóreos, Silva \& Shepherd (1986) concluíram que a mata atlântica do RJ (a partir da amostra de Teresópolis) é muito diferente das demais comparadas.

- nenhuma das espécies citadas acima teve ocorrência registrada para as matas mesófilas semidecíduas do interior (Depressão Periférica até Planalto Ocidental).

Espécies com limite de distribuição sul em SP, estendendose ao Nordeste ou Centro-Oeste e que apresentaram ampla distribuição em SP como Croton floribundus (Euphorbiaceae), Senna macranthera (Leguminosae-Caesalpinioideae) e Machaerium nyctitans (Leguminosae-Papilionoideae) são características de estádios sucessionais iniciais (Gandolfi 1991). 


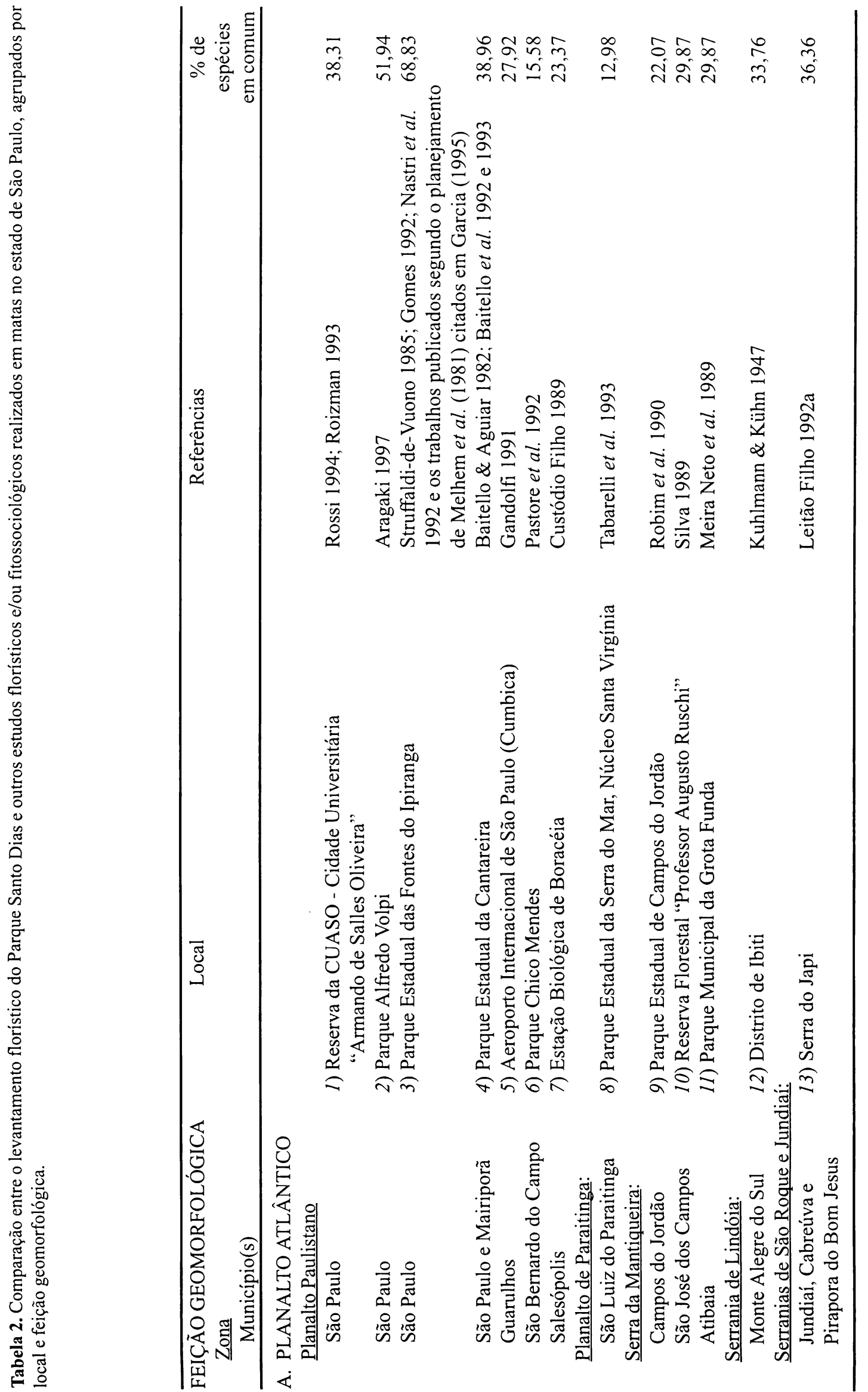




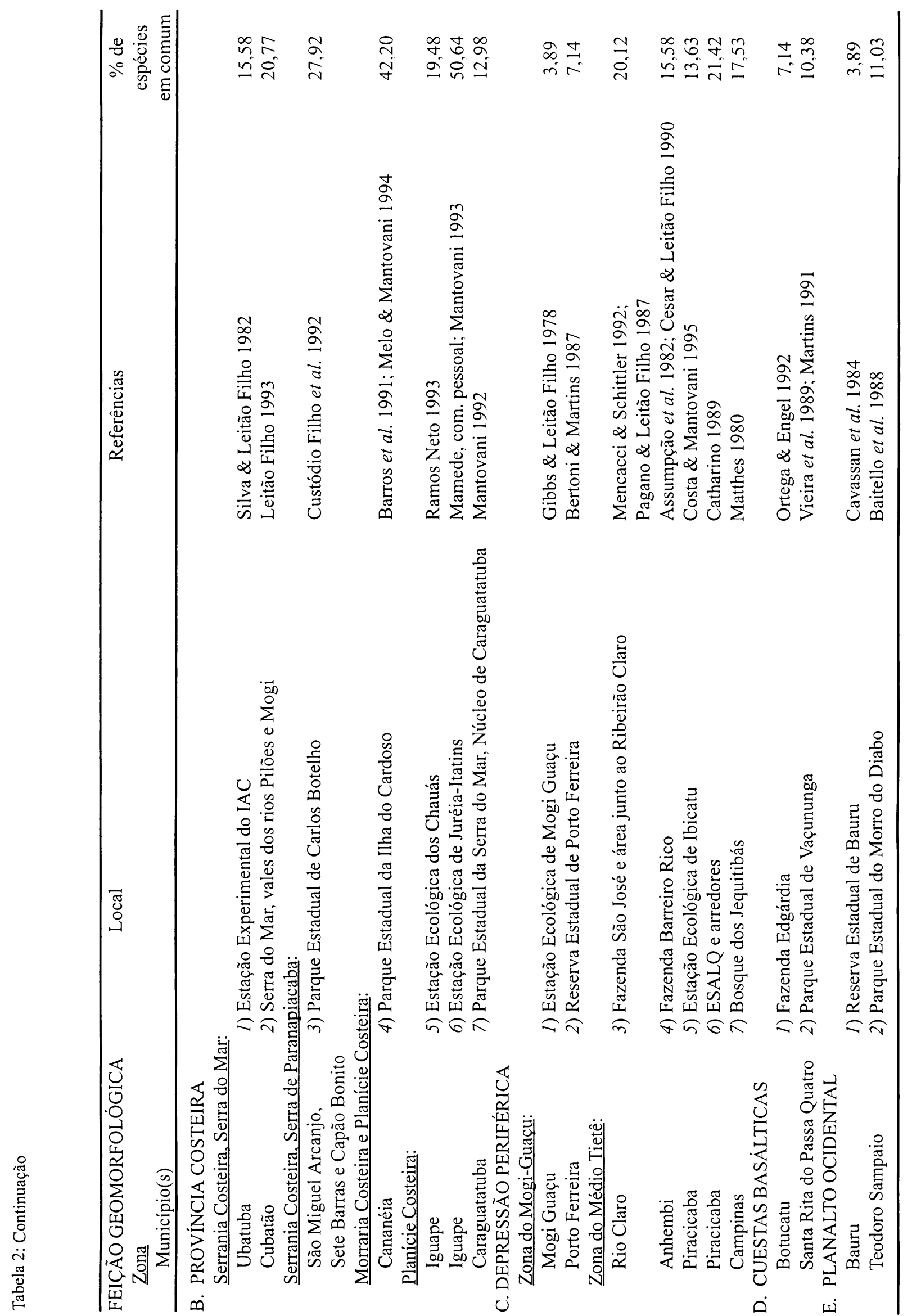




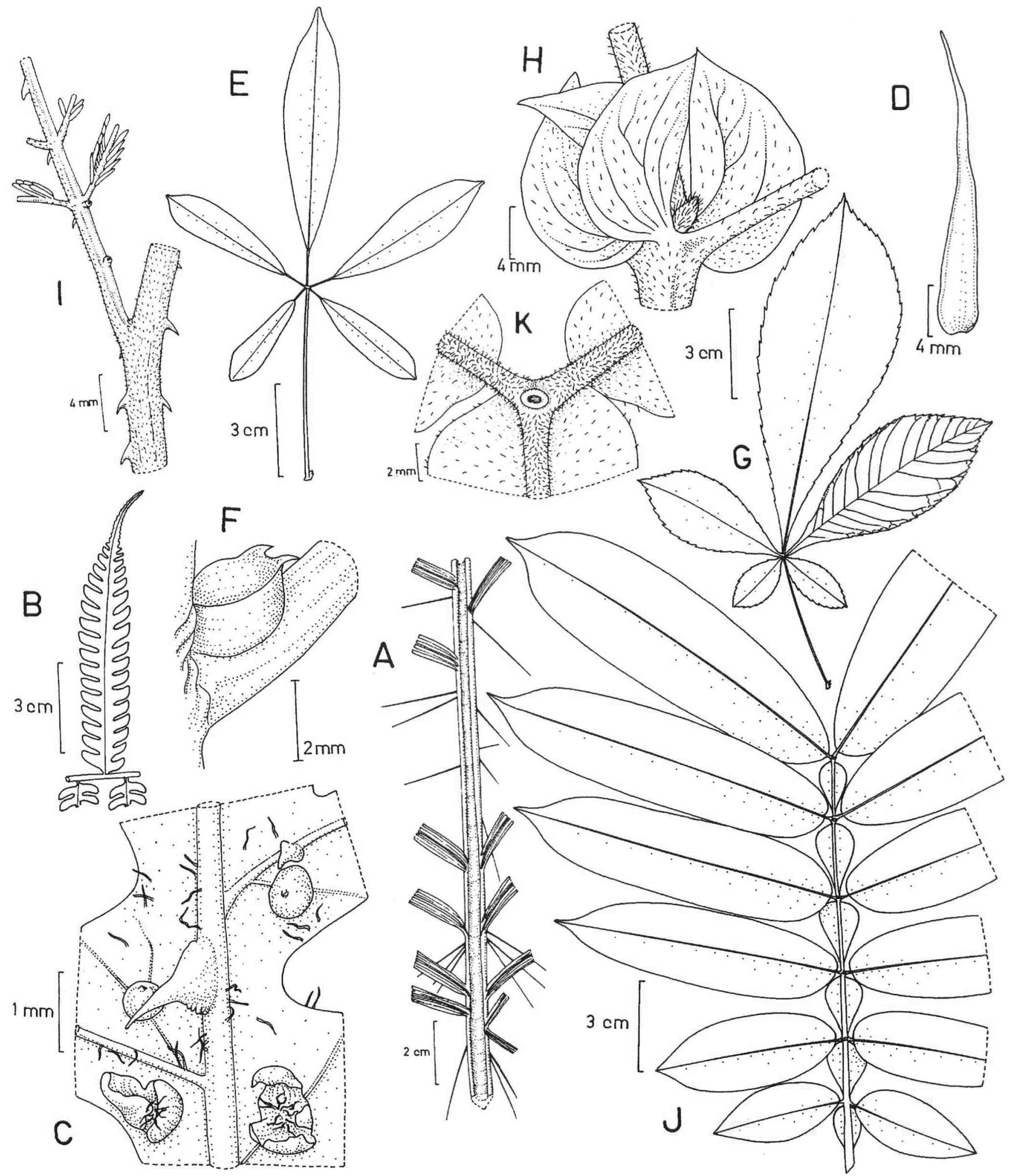

Fig. 2: Bactris setosa Mart. - Palmae: A, raque foliar (Garcia 283). Cyathea delgadii Sternb. - Cyatheaceae: B, pínulas; C, soros e escamas da pínula; D, escamas do pecíolo (Garcia 424). Didymopanax angustissimum Marchal - Araliaceae: E, folha; F, estípula (Garcia 413). Lamanonia ternata Vell. - Cunoniaceae: G, folha; H, estípulas (G: Garcia 334; H: Garcia 444). Acacia plumosa Lowe - LeguminosaeMimosoideae: I, ramo e pecíolo (Garcia 365). Inga sessilis (Vell.) Mart. - Leguminosae-Mimosoideae: J, folha; K, glândula junto ao par apical de folíolos (Garcia 378). 


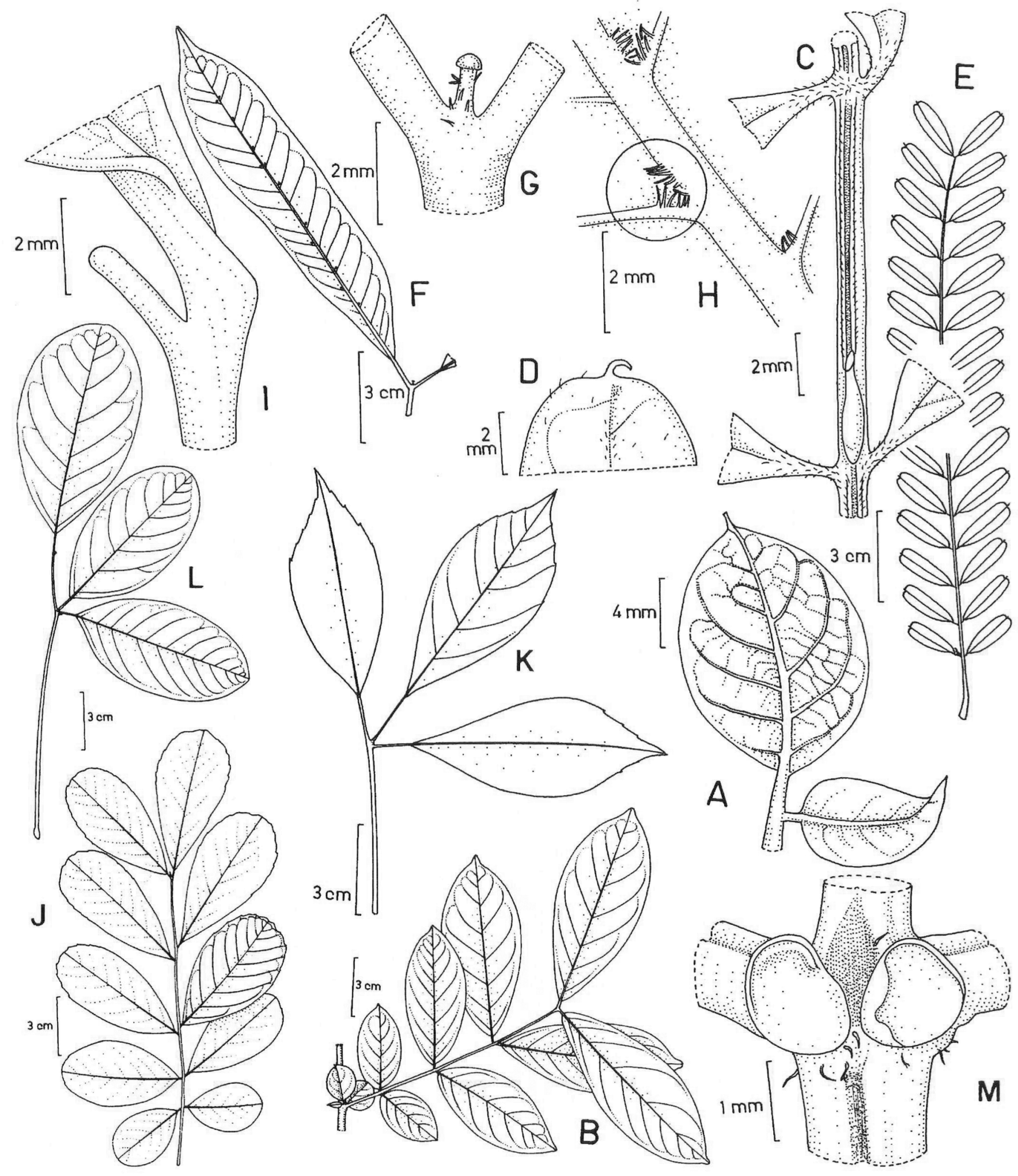

Fig. 3: Sclerolobium denudatum Vogel - Leguminosae-Caesalpinioideae: A, estípula; B, folha (A: Garcia 165; B: Garcia 254). Senna multijuga (Rich.) H.S.Irwin \& Barneby - Leguminosae-Caesalpinioideae: C, glândula entre folíolos; D, ápice do folíolo; E, folha (Garcia 348). Cabralea canjerana (Vell.) Mart. - Meliaceae: F, folíolo do par apical; G, folíolo rudimentar; H, domácias (Garcia 244). Cupania oblongifolia Mart. - Sapindaceae: I, folíolo rudimentar; J, folha (Garcia 26). Allophylus petiolulatus Radlk. - Sapindaceae: K, folha (Garcia 73). Erythrina falcata Benth. Leguminosae-Papilionoideae: L, foha; M, estipelas (Garcia 514). 


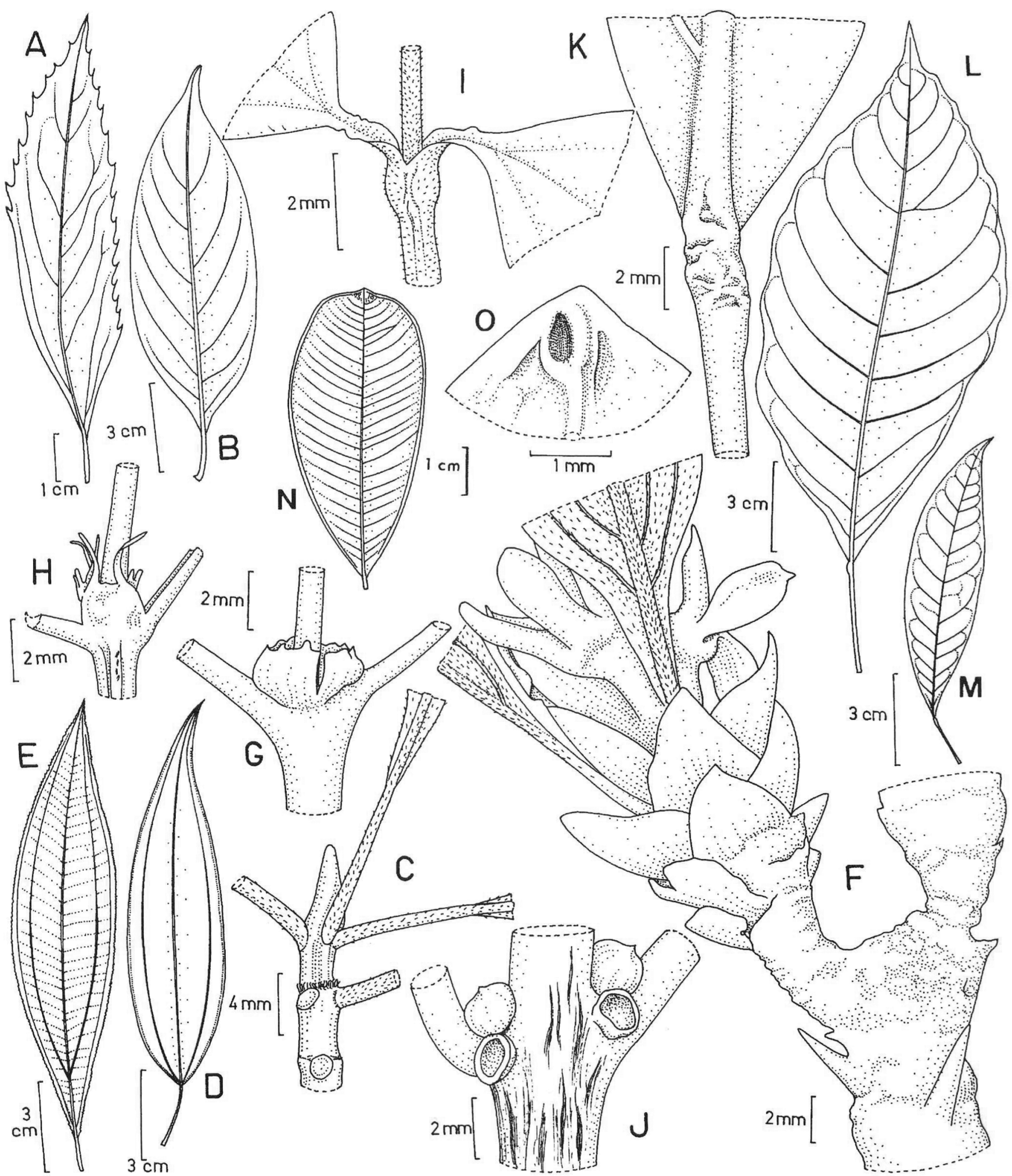

Fig. 4: Euplassa hoehnei Sleumer - Proteaceae: A, folíolo (Garcia 423). Amaioua intermedia Mart. - Rubiaceae: B, folha; C, ramo e estípula (Garcia 279). Miconia cubatanensis Hoehne - Melastomataceae: D, folha (Garcia 404). Leandra melastomoides Raddi - Melastomataceae: E, folha (Garcia 285). Randia armata (Sw.) DC. - Rubiaceae: F, ramo, espinhos e estípulas (Garcia 516 \& Godoy). Psychotria cephalantha (Müll. Arg.) Standl. - Rubiaceae: G, estípulas (Garcia 435). Psychotria vellosiana Benth. - Rubiaceae: H, estípulas (Garcia 262). Strichnos brasiliensis (Spreng.) Mart. - Loganiaceae: I, estípulas reduzidas (Garcia 428). Qualea selloi Warm. - Vochysiaceae: J, estípulas e gemas (Garcia 47). Sloanea guianensis (Aubl.) Benth. - Elaeocarpaceae: K, ápice do pecíolo; L, folha (Garcia 338). Sloanea monosperma Vell. Elaeocarpaceae: M, folha (Garcia 512). Lafoensia replicata Pohl - Lythraceae: N, folha; O, poro no ápice foliar (Garcia 440). 


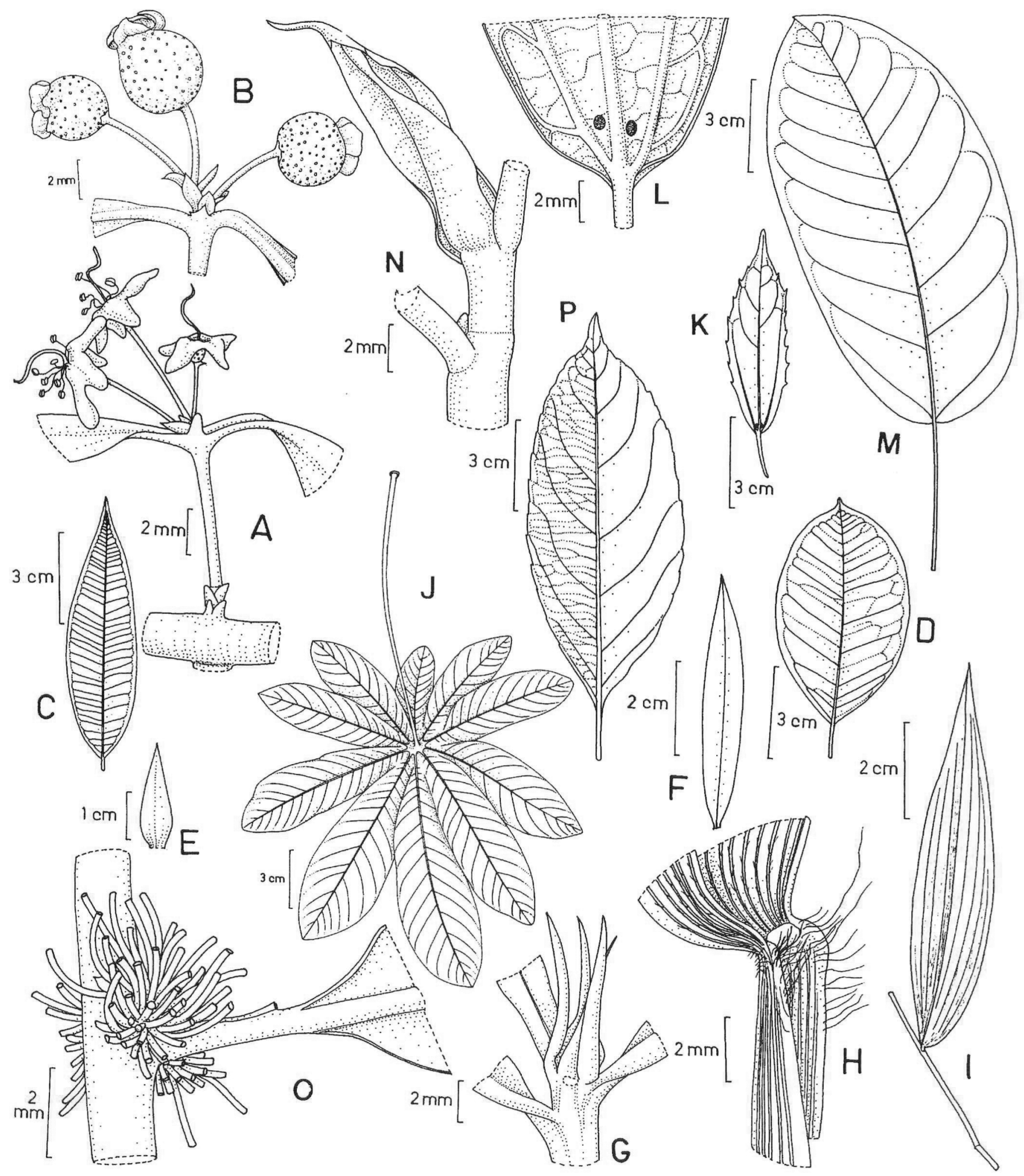

Fig. 5: Eugenia excelsa O. Berg - Myrtaceae: A, ramo novo com catafilos na base e ápice; B, catafilos persistentes durante frutificação (Garcia 224). Plinia anonyma Sobral - Myrtaceae: C, folha (Garcia 171). Eugenia cerasiflora Miq. - Myrtaceae: D, folha (Garcia 118). Araucaria angustifolia (Bertol.) Kuntze - Araucariaceae: E, folha (Garcia 78). Podocarpus sellowii Klotzsch ex Endl. - Podocarpaceae: F, folha; G, escamas da gema terminal (Garcia 400). Lasiacis divaricata (L.) Hitchc. - Gramineae: H, bainha, lígula e base da lâmina; I, folha (Garcia 135). Cecropia hololeuca Miq. - Cecropiaceae: J, folha (Garcia 54). Alchornea triplinervia (Spreng.) Müll. Arg. - Euphorbiaceae: K, folha; L, glândulas (Garcia 388). Ficus luschnatiana (Miq.) Miq. - Moraceae: M, folha; N, estípulas (Garcia 208). Casearia sylvestris Sw. - Flacourtiaceae: O, base persistente dos pedicelos (Garcia 250). Xylosma glaberrimum Sleumer - Flacourtiaceae: $\mathrm{P}$, folha (Garcia 421). 


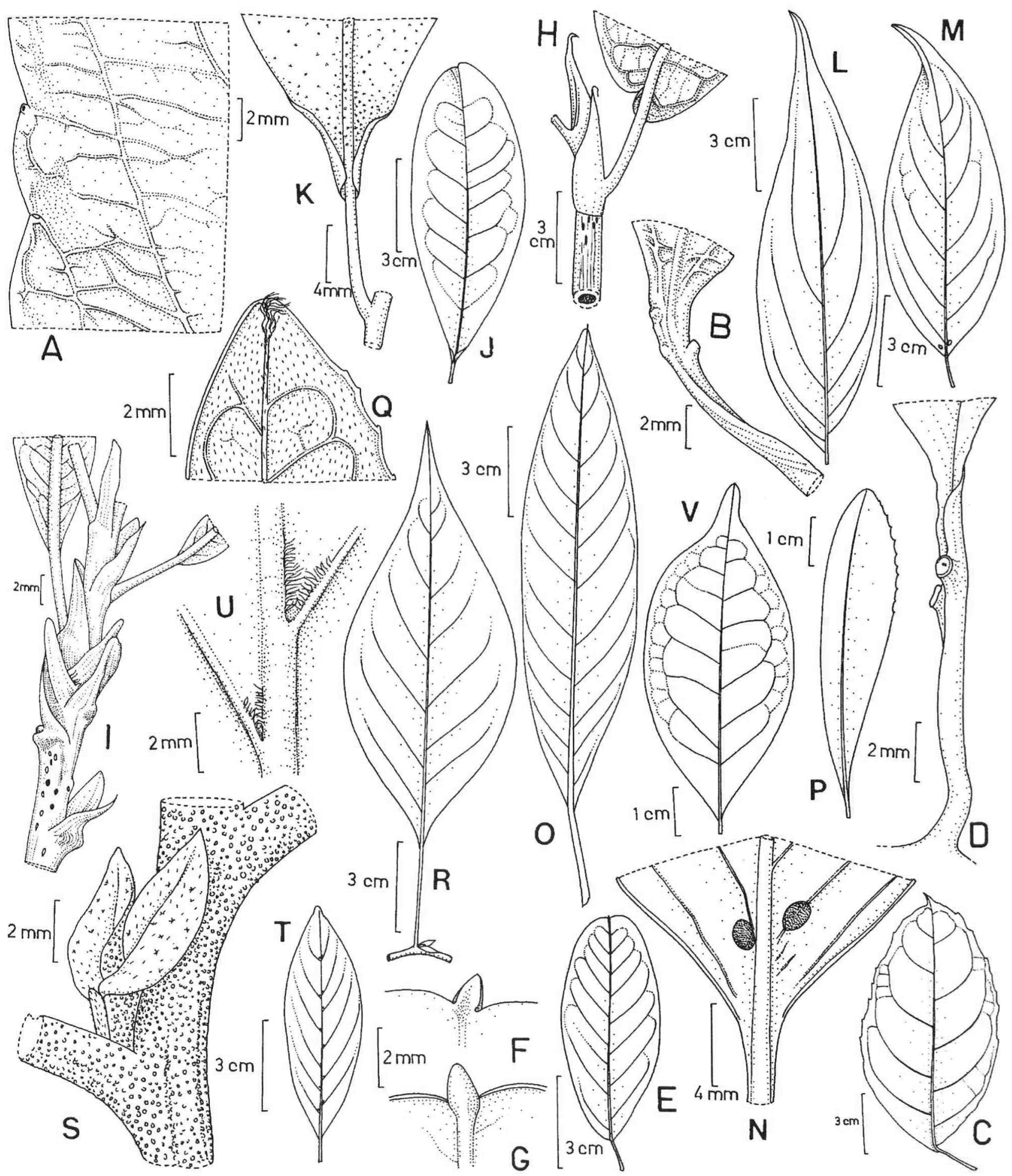

Fig. 6: Xylosma glaberrimum Sleumer - Flacourtiaceae: A, margem foliar com glândulas; B, base foliar (Garcia 421). Tetrorchidium rubrivenium Poepp. \& Endl. - Euphorbiaceae: C, folha; D, pecíolo com glândulas (Garcia 416). Seguieria langsdorfii Moq. - Phytolaccaceae: E, folha; F, múcron, vista adaxial; G, múcron, vista abaxial (Garcia 133). Coccoloba warmingii Meisn. - Polygonaceae: H, ócrea (Garcia 374). Erythroxylum deciduum A.St.-Hil. - Erythroxylaceae: I, ramo com estípulas (Garcia 157).Pera glabrata (Schott) Baill. - Euphorbiaceae: J, folha; K, base foliar com domácias (Garcia 330). Piper gaudichaudianum Kunth. - Piperaceae: L, folha (Garcia 107). Prunus myrtifolia (L.) Urban - Rosaceae: M, folha; N, base foliar com glândulas (Garcia 366). Vernonia diffusa Less. - Compositae: O, folha (Garcia 158). Gordonia fruticosa (Schrad.) H. King - Theaceae: P, folha; Q, ápice foliar, face abaxial (Garcia 283). Solanum granuloso-leprosum Dunal - Solanaceae: R, folha; S, folhas axilares (Garcia 111). Nectandra barbellata Coe-Teix. - Lauraceae: T, folha; U, domácias (Garcia 231). Ocotea teleiandra (Meisn.) Mez - Lauraceae: V, folha (Garcia 286). 
Espécies com limite de distribuição norte em SP, quando consideradas em conjunto com as espécies cuja distribuição se estende pelo sul e sudeste brasileiros, perfazem $43,51 \%$ do total encontrado no parque, indicando uma grande influência da flora meridional na flora local, como também foi enfatizado por Mantovani (1993) para a Juréia.

A mata atlântica de SC e as matas de planalto de SP (embora não amostrando o Planalto Paulistano) foram consideradas com alta similaridade florística por Silva \& Shepherd (1986) ao compararem os gêneros co-ocorrentes. Ao discutirem as relações florísticas da mata da CUASO (Rossi 1994) e do Parque do Estado (Gomes 1992), ambas no município de São Paulo, estes autores consideraram alta a similaridade com as matas catarinenses do vale do Itajaí (driádicas), que apresentam condições climáticas semelhantes, devido à compensação do efeito da latitude em SC pela altitude em SP.

Entre os elementos florísticos associados às matas de araucária (napeádicos), presentes no parque, ressalta-se a ocorrência da própria Araucaria angustifolia (Araucariaceae) de forma esporádica, o que é interpretado em SC (Reitz \& Klein 1966) como uma substituição da mata de araucária pela mata atlântica ou pela mata da bacia do Uruguai. Isto é reforçado no estudo de Backes (1999) em que são analisadas as condições climáticas de 15 localidades, inclusive São Paulo, onde a espécie ocorre. O autor ressalta que a espécie encontra-se em declínio devido à existência de condições climáticas mais favoráveis à expansão de espécies tropicais. Fatores antrópicos também podem ter contribuído para o declínio desta espécie no município de São Paulo, como a coleta intensiva das sementes, praticada na época colonial (Langenbuch 1968, apud Garcia 1995) associada à expansão urbana.

Veloso et al. (1991) interpretam a distribuição disjunta das matas de araucária como o resultado da expansão da Araucaria angustifolia a partir de "refúgios" na Serra da Mantiqueira, colonizando o Planalto Meridional (PR-SC) após um período de intensa atividade vulcânica. Segundo estes autores, em períodos geológicos anteriores, mais frios e secos, as gimnospermas teriam tido uma ampla distribuição no Brasil. A extensão pretérita das matas de araucária poderia ser inferida, segundo Oliveira Filho \& Ratter (1995) ao se observar a distribuição atual de espécies a elas sempre associadas, como Podocarpus sellowii (Podocarpaceae) e Drimys brasiliensis (Winteraceae), em matas isoladas, em altitudes elevadas, na Cadeia do Espinhaço e Planalto Central

Salis et al. (1995), ao compararem por análise de agrupamento 26 matas de planalto em SP, concluíram que são distingüidos floristicamente 2 grupos; um deles, menor em extensão, é mais homogêneo, englobando áreas com altitudes maiores que $700 \mathrm{~m} . \mathrm{s}$.m. e climas mais frios e úmidos, incluindo amostras dos municípios de Angatuba, Atibaia, Guarulhos, Jundiaí, São José dos Campos e São Paulo. Neste grupo foram registradas 24 espécies que os autores consideraram exclusivas, sendo que 8 são encontradas no Parque Santo
Dias: Alchornea sidifolia (Euphorbiaceae), Anadenanthera colubrina (Leguminosae-Mimosoideae), Didymopanax angustissimum (Araliaceae), Guatteria australis (Annonaceae), Ilex dumosa (Aquifoliaceae), Ocotea lanata (Lauraceae), Solanum variabile (Solanaceae) e Vochysia magnifica (Vochysiaceae).

Quando se considera todas as áreas comparadas em SP, o Parque do Estado foi a que apresentou o maior número de espécies em comum com o Parque Santo Dias $(68,83 \%$ do total de espécies do parque). Em seguida, com $51,94 \%$ das espécies em comum, figurou o Parque Alfredo Volpi. Em terceiro lugar em número de espécies em comum ficou a Estação Ecológica da Juréia com $50,64 \%$ do total do parque.

Os menores valores de espécies em comum foram observados para a mata mesófila semidecídua de Bauru (com 3,89\%) e para as matas ripárias na Depressão Periférica em Mogi Guaçu (com 3,89\%) e Porto Ferreira (com 7,14\%), bem como nas cuestas basálticas em Botucatu (com 7,14\%). Estes dados parecem indicar uma pequena ligação florística destas matas ripárias com o parque, apesar de este tipo de mata ser considerado como corredor para a dispersão de espécies de ampla distribuição (Mantovani 1993; Oliveira Filho \& Ratter 1995).

Ao se comparar as áreas de forma agrupada, por feição geomorfológica, constata-se que o Planalto Atlântico, que inclui o Planalto Paulistano, é de longe a feição que compartilha o maior número de espécies $(92,20 \%$ de co-ocorrência em pelo menos uma das áreas comparadas). Em segundo lugar encontra-se a Província Costeira, com 64,28\% de espécies compartilhadas (do total do parque).

Em direção ao interior do estado, no sentido norte e oeste, observa-se um gradiente decrescente no número de espécies em comum com o parque: $42,20 \%$ para a Depressão Periférica, $13,63 \%$ para as Cuestas Basálticas e $12,3 \%$ para o Planalto Ocidental. Esta situação parece refletir as mudanças de condições ambientais observadas a partir da Depressão

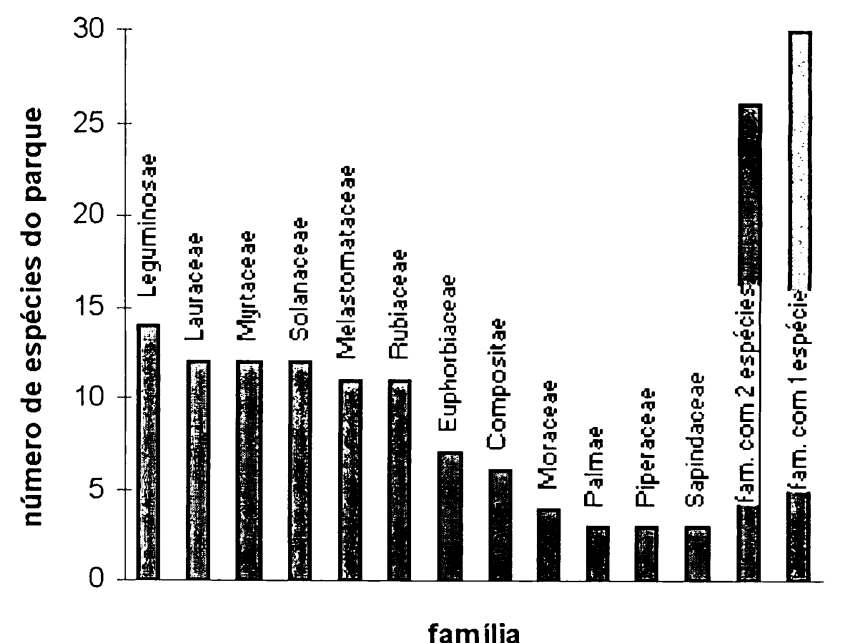

Fig. 7: Distribuição das famílias pelo número de espécies do Parque Santo Dias 
Periférica (Catharino 1989): relevo em geral menos acidentado e sazonalidade climática mais acentuada, com temperaturas mais elevadas e pluviosidades menores.

Quando considerada a flora arbórea dos cerrados (Leitão Filho 1992b) encontra-se 10,4\% de espécies do parque em comum, valor menor que o encontrado para os agrupamentos indicados, à exceção das matas ripárias da Depressão Periférica. Na análise florística de Leitão Filho (1993) para a mata atlântica em Cubatão, 3\% das espécies das áreas amostradas foram encontrados com co-ocorrência nos cerrados. Estes dados sugerem também um gradiente na distribuição de espécies do cerrado entre o interior e litoral. Contudo, conforme ressaltou Leitão Filho (1992b), estes dados podem ser interpretados como a capacidade de penetração de espécies peculiares da mata mesófila semidecídua no cerrado, especialmente cerradões, ao invés da situação contrária.

Todavia, a existência de espécies herbáceas e arbustivas características do cerrado, no Planalto Paulistano pode ser observada:

- no mapa fitogeográfico de Hueck (1956), que assinala elementos de cerrado para os atuais municípios de Osasco e São Paulo (bairros do Butantã e Lapa);

- em exsicatas de materiais coletados no Parque do Estado;

- no trabalho de Joly (1950) sobre os campos do Butantã (atual campus da USP), destacando a presença de elementos oreádicos e napeádicos com limites de distribuição na Bacia de São Paulo.

Pode-se concluir que os dados encontrados para o Parque Santo Dias corroboram as conclusões de trabalhos realizados anteriormente, quanto ao aspecto transicional das matas do Planalto Atlântico e em especial do Planalto Paulistano. O parque possui elementos florísticos característicos das matas atlânticas, especialmente do sul e de matas mesófilas semidecíduas de altitude, inclusive com espécies de distribuição disjunta com a Serra dos Órgãos. A presença de elementos de cerrado (oreádicos) e das matas de araucária (napeádicos) também está de acordo com as conclusões de Joly (1950) para os campos do Butantã.

Para explicar a diversidade de elementos florísticos no Planalto Paulistano, Struffaldi-de-Vuono (1985), ao analisar a flora do Parque do Estado, concluiu que a área encontravase no cruzamento de rotas migratórias de floras distintas. Contudo, Oliveira Filho \& Ratter (1995) ao analisarem a origem das matas do Brasil Central, consideram que as evidências palinológicas suportam a idéia de mudanças florísticas associadas a alterações climáticas do Quaternário, com períodos de ligação entre as atuais matas amazônica e atlântica, através de matas de galeria; períodos mais frios, com grande extensão das matas de araucária; períodos mais quentes e secos com expansão dos cerrados; e o período atual, propício à expansão das matas mesófilas semidecíduas sobre as áreas de cerrado. Desta forma, a diversidade florística observada para o Planalto Paulistano pode ser devida à contribuição de floras distintas que teriam ocorrido na região, sem terem sido completamente substituídas por ocasião das mudanças climáticas.

\section{Aspectos fisionômicos e estruturais}

A partir do diagrama de perfil realizado (Fig. 8), constatase uma mata com dossel de até $20 \mathrm{~m}$ de altura, descontínuo, com Sclerolobium denudatum (Leguminosae-Caesalpinioideae) abundante e Didymopanax angustissimum (Araliaceae). Esta situação não é uniforme no parque, sendo também comuns no dossel, em outros trechos do parque: Tapirira guianensis (Anacardiaceae), Alchornea sidifolia e Pera glabrata (Euphorbiaceae), Anadenanthera colubrina (LeguminosaeMimosoideae), Cedrela fissilis (Meliaceae), Guapira opposita (Nyctaginaceae) e Vochysia magnifica (Vochysiaceae). Espécies observadas no dossel, mas pouco comuns são: Podocarpus sellowii (Podocarpaceae), Lamanonia ternata (Cunoniaceae), Nectandra oppositifolia (Lauraceae), Cassia ferruginea (Leguminosae - Caesalpinioideae), Erythrina falcata e Platymiscium floribundum (Leguminosae Papilionoideae), Miconia cabussu (Melastomataceae), Ficus organensis (Moraceae), Coccoloba warmingii (Polygonaceae), Syagrus romanzoffiana (Palmae), entre outras.

A descontinuidade observada no dossel em parte ilustra a não inclusão do tronco na parcela amostrada, apesar de a respectiva copa ocupar espaço no dossel; mas principalmente deve-se à queda de árvores, abrindo clareiras, seja por causa de tempestades, como observado no período de coletas, seja pela ação antrópica passada. Quanto à abundância de Sclerolobium denudatum no trecho em questão, observa-se que o mesmo não ocorre em estratos inferiores, abaixo dos critérios para inclusão na amostragem na parcela, indicando possivelmente alterações na estrutura etária da população, o que pode refletir distúrbios de origem natural ou antrópica (Bazzaz 1983).

Apesar de se registrar no dossel a presença de árvores caducifólias ou com intensa renovação foliar (semicaducifólias), tais espécies não se constituem em elemento fisionômico predominante da mata. Esta condição, associada à localização da área (latitude, altitude e proximidade do mar) permite a classificação da mata do parque como floresta ombrófila densa montana, ou floresta pluvial tropical, de acordo com a proposta por Veloso et al. (1991) e mapeada para o Brasil pelo IBGE (1993).

No estrato intermediário, aproximadamente entre 5 e 15 $\mathrm{m}$ de altura (Fig. 8), há uma descontinuidade na ocupação espacial, que pode ser atribuída a cortes seletivos e à abertura de clareiras por queda de árvores maiores. Este estrato pode ser mais densamente ocupado, em outros locais do parque, encontrando-se grande parte das espécies registradas.

No estrato inferior são encontrados muitos indivíduos de arbustos e arvoretas, adultos entre 1,5 e $5 \mathrm{~m}$ de altura, além de indivíduos jovens de árvores de estratos mais altos. As diferenças morfológicas entre estes indivíduos jovens (sujeitos a maior sombreamento) e os mais velhos podem ser 

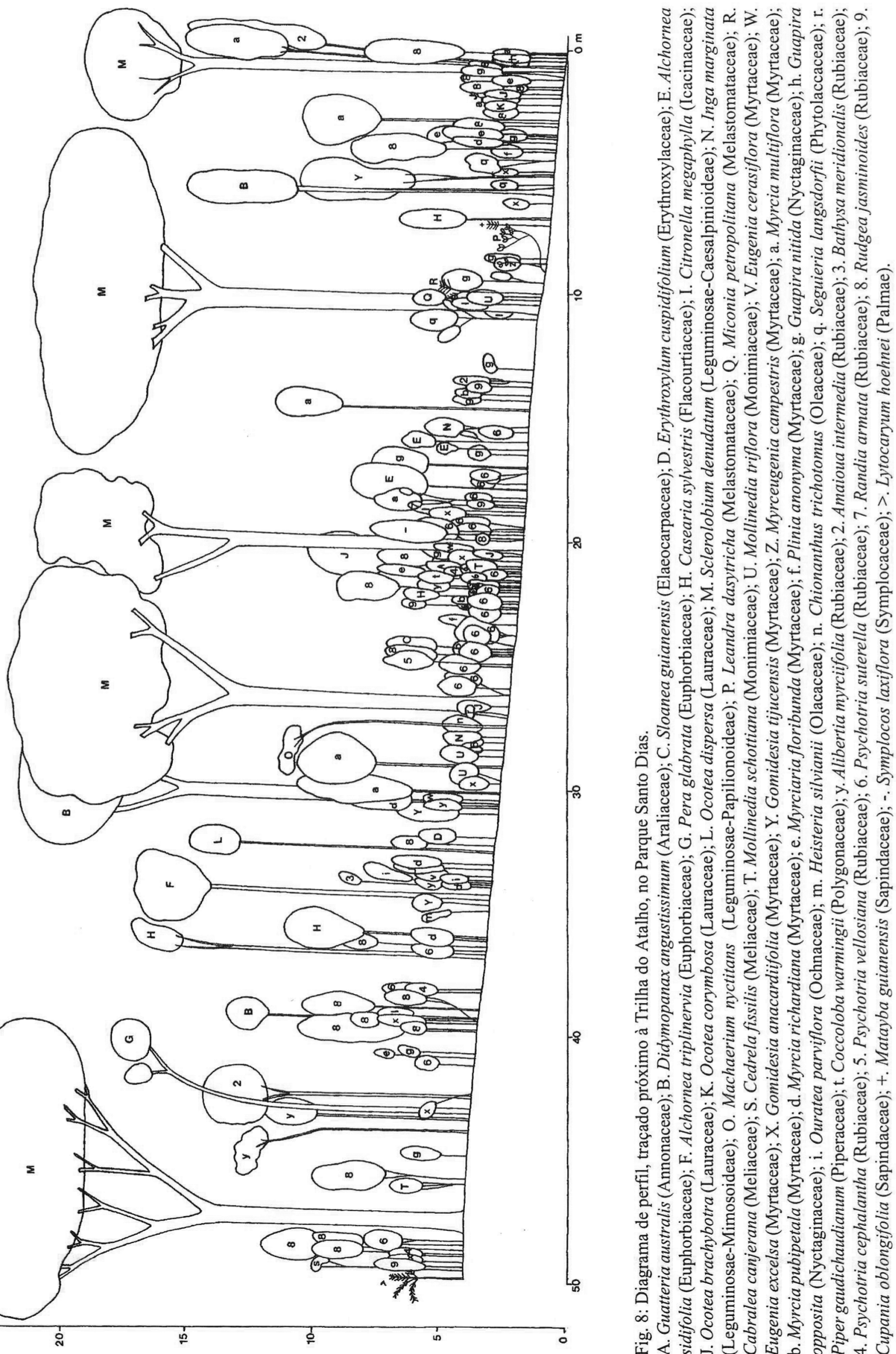
significativas, especialmente nas dimensões foliares, como observado para Podocarpus sellowii (Podocarpaceae) e Coccoloba warmingii (Polygonaceae).

A grande quantidade de arvoretas pode indicar a recomposição da vegetação, aproveitando espaços não ocupados dos estratos superiores, sobressaindo-se no diagrama de perfil: Myrcia multiflora (Myrtaceae), Guapira opposita (Nyctaginaceae) e Rudgea jasminoides (Rubiaceae), que são comuns em várias partes do parque. Espécies com desenvolvimento pleno e comuns neste estrato também o são para outras áreas do parque, especialmente Psychotria suterella (Rubiaceae). Espécies comuns neste estrato mas pouco amostradas no perfil são: Leandra dasytricha (Melastomataceae), Piper gaudichaudianum (Piperaceae) e Lytocaryum hoehnei (Palmae).

Nos trechos do diagrama de perfil em que há uma diminuição no número de indivíduos do estrato inferior foram observados uma trilha de uso aparentemente freqüente (visto a pequena quantidade de plantas jovens) e áreas ocupadas por plantas bambusóides como Chusquea capituliflora que, junto com Lasiacis divaricata (ambas Gramineae), chegam a se estender por grandes áreas abaixo da Trilha Principal, o que pode dificultar o estabelecimento de espécies arbóreas.

Nos trechos do parque em que a mata sofreu danos ambientais graves, a estratificação inexiste ou é bastante reduzida, com abundância de espécies típicas de estádios sucessionais iniciais, como observado para Guarulhos (SP) por Gandolfi (1991): Cecropia glazioui e C. hololeuca (Cecropiaceae), Baccharis semiserrata e Vernonia polyanthes (Compositae), Alchornea sidifolia e Croton floribundus (Euphorbiaceae), Piptadenia gonoacantha (LeguminosaeMimosoideae), Solanum granuloso-leprosum (Solanaceae) e Trema micrantha (Ulmaceae).

Essas observações necessitam de uma abordagem quantitativa, a partir de estudos fitossociológicos, para procurar estabelecer as relações entre as espécies registradas e detectar mudanças na estrutura da comunidade, face às pressões ambientais existentes como: isolamento da área, com possíveis alterações no fluxo de animais polinizadores e dispersores de dissemínulos; processos de competição e ação antrópica. Preliminarmente, contudo, pode-se verificar o aspecto de mosaico fisionômico da vegetação, resultante de variações de estádios sucessionais e de abundância das espécies, heterogeneidade comumente observada para as florestas tropicais (Janzen 1980; Mantovani 1993), especialmente quando submetidas a graus variados de distúrbios (Bazzaz 1983). As considerações sobre os estádios sucessionais amostrados sinalizam a influência dos mesmos sobre a análise florística, apresentada anteriormente, uma vez que as áreas comparadas possuem diferentes históricos de interferência antrópica e estudos fitossociológicos usados para comparação podem utilizar critérios de amostragem que podem representar melhor determinados estádios sucessionais.

Foram encontradas no interior ou borda da mata, mas não incluídas na chave e comparações florísticas, as seguintes espécies exóticas arbóreas ou arbustivas, algumas delas já subespontâneas na paisagem paulistana e que indicam ações antrópicas na área: Archontophoenix cunninghamiana Wendl. \& Drude (Palmae); Citrus limon (L.) Burm.f. (Rutaceae); Eriobotrya japonica (Thumb.) Lindl. (Rosaceae); Eucalyptus tereticornis Sm. (Myrtaceae); Malvaviscus arboreus Cav. (Malvaceae); Morus nigra L. (Moraceae); Pittosporum undulatum Venten. (Pittosporaceae); Ricinus communis L. (Euphorbiaceae); Spathodea campanulata Beauv. (Bignoniaceae). Foram encontradas as seguintes espécies arbóreas exóticas, já existentes nas áreas não florestadas do parque, por ocasião da implantação do mesmo: Acacia mearnsii De Wild. (Leguminosae-Mimosoideae); Persea americana Mill. (Lauraceae); Tecoma stans (L.) H. B. K. (Bignoniaceae); Taxodium distichum (L.) Rich. (Taxodiaceae). Foram registradas as seguintes espécies arbóreas introduzidas com a implantação do parque nas áreas sem cobertura florestal: Chorisia speciosa A. St.-Hil. (Bombacaceae); Syagrus romanzoffiana (Cham.) Glasman (Palmae); Tabebuia spp (Bignoniaceae); Tetrapanax papyriferus C. Koch (Araliaceae); Tibouchina granulosa Cogn. (Melastomataceae). Sambucus australis (Caprifoliaceae), apesar de ser incluída na listagem de espécies nativas, dada sua distribuição geográfica, pode ter sua ocorrência no parque devido à ação antrópica, uma vez que a espécie é cultivada em quintais como medicinal.

\section{Considerações sobre as síndromes de dispersão das espécies}

Os resultados da análise das síndromes de dispersão de diásporos, das espécies arbóreas e arbustivas do Parque Santo Dias, estão apresentados na Tabela 1. Foi constatada a predominância de espécies com características de zoocoria ( $75,97 \%$ do total de espécies do parque), o que está de acordo com o observado por Janzen (1980) para as florestas tropicais em geral. O mesmo fato foi igualmente assinalado por Mantovani (1993) para a mata atlântica paulista e por Rossi (1994) para a mata da CUASO, no Planalto Paulistano.

Entre as plantas zoocóricas do parque, encontram-se as Rubiaceae, Myrtaceae, Lauraceae, Moraceae, Melastomataceae (exceto Tibouchina spp) e Solanaceae, bem representadas nos estratos intermediário e inferior da mata. Com exceção de Pavonia spp (Malvaceae) e Triumfetta semitriloba (Tiliaceae), que apresentam diásporos com características de epizoocoria, as demais plantas desta categoria são endozoocóricas potenciais.

A anemocoria foi apresentada por $16,88 \%$ das espécies do parque e encontra-se associada a arbustos e arvoretas de borda ou clareiras e a árvores do dossel, destacando-se, pelo número de espécies, as Compositae e Leguminosae.

Poderiam ser enquadradas como autocóricas, face à deiscência explosiva ou elástica dos frutos, $5,85 \%$ das espécies do parque, pertencendo às Euphorbiaceae e Leguminosae. As 2 espécies de Gramineae $(1,30 \%$ do total 
do parque) não foram classificadas pela dificuldade de inclusão nas categorias propostas.

Ressalta-se que, como sugere Janzen (1980), os padrões de dispersão devem ser analisados com ressalvas, para inferir relações entre fauna e flora, haja visto: as possíveis diferenças nas taxas de evolução entre plantas e animais; as alterações de ocorrência e freqüência de animais face à ação antrópica, seja devido à caça, seja pelo isolamento das áreas florestais fragmentadas; e a possibilidade de ocorrência de mais de um tipo de dispersão para a mesma espécie. Janzen (1980) indica ainda que a disponibilidade de frutos com características de zoocoria, por si, não indicaria que a dispersão esteja ocorrendo através de animais, mas, sem dúvida, a ausência destes acarretaria modificações na estrutura da comunidade vegetal, com alterações de ocupação espacial e intensificação de processos de competição intra-específica.

Tendo em vista que a mata do parque, como outros remanescentes florestais do município de São Paulo, apresentam-se como "ilhas de vegetação" na malha urbana, possivelmente o fluxo gênico entre as populações destes remanescentes, para as espécies zoocóricas, deve estar mais dependente de aves com hábitats diversificados e morcegos, uma vez que, nessas circunstâncias, são altamente limitados os deslocamentos de mamíferos terrestres ou arborícolas e aves de hábitos estritamente associados a matas.

Outro fator que poderia estar dificultando a dispersão das espécies e a manutenção do fluxo gênico, entre as populações dessas "ilhas de mata" distantes, é a pequena possibilidade de sobrevivência de espécies florestais na malha urbana, seja devido à competição e predomínio de espécies exóticas e/ou ruderais nestas áreas, seja pela ação antrópica, através da eliminação de possíveis plantas jovens ao se realizar a conservação de áreas ajardinadas, bem como pelos cortes e queimadas realizados nas áreas livres de edı11cições.

\section{Considerações finais}

Os dados apresentados mostram a importância da conservação dos remanescentes florestais existentes no município de São Paulo. Numa área já isolada pela expansão urbana, como o Parque Santo Dias, foi possível encontrar espécies de distribuição restrita, além de se registrar uma espécie anteriormente não citada para o estado (Plinia anonyma - Myrtaceae). Neste sentido, faz-se necessário ampliar esforços para a conservação de áreas com vegetação nativa remanescente.

Como foi observado para o parque, a região do Planalto Paulistano constitui-se em área de encontro de floras diversas. Apesar da relativa facilidade de acesso, grande parte das áreas florestais remanescentes no município, especialmente nas zonas rurais leste e sul, têm sido pouco estudadas, situação que ao ser revertida poderá trazer valiosas informações para estudos florísticos e fitogeográficos, indispensáveis para a ação conservacionista.
O presente trabalho também aponta para a urgente necessidade de utilização de estudos florísticos e fitossociológicos para a execução de programas de manejo dos parques, os quais devem estar integrados a programas de educação ambiental, de forma que as pressões antrópicas sobre o parque não comprometam o patrimônio genético ainda existente. A título de exemplo citamos:

- Produzir mudas para utilização no próprio parque, a partir da coleta de sementes de indivíduos selecionados como matrizes, aproveitando a indicação de localização apresentada em Garcia (1995). O excedente de produção poderia ser encaminhado para utilização em outros parques ou ainda em áreas livres da vizinhança, de modo a melhorar as condições de trânsito a animais polinizadores e dispersores de sementes. Priorizar o plantio de espécies secundárias iniciais e secundárias tardias para acelerar a sucessão em áreas degradadas, atualmente em fases iniciais da sucessão.

- Produzir mudas de espécies pobremente documentadas para o Planalto Paulistano e que podem estar mais suscetíveis de extinção local, como: Plinia anonyma, Tibouchina saldanhae, Lytocaryum hoehnei, Euplassa hoehnei, Qualea selloi, Araucaria angustifolia. Tais espécies poderiam ser plantadas também em jardins botânicos, visando sua divulgação e conservação.

- Substituir espécies exóticas encontradas nas bordas ou interior da mata por nativas. Espécies ornamentais de pequeno porte, como Archontophoenix cunninghamiana, poderiam ser transplantadas para áreas ajardinadas.

- Fechar trilhas da mata que vêm sendo abertas indevidamente pela população usuária do parque.

\section{Agradecimentos}

Os autores agradecem a Waldir Mantovani (Departamento de Ecologia Geral - IB - USP) e a Maria Cândida Henrique Mamede (Instituto de Botânica), pelas sugestões encaminhadas. Aos curadores dos herbários citados, pelo uso das instalações; aos especialistas que revisaram identificações e ao Departamento de Parques e Áreas Verdes pelo apoio logístico.

\section{Referências}

ARAGAKI, S. 1997. Floristica e estrutura de trecho remanescente de floresta no Planalto Paulistano (SP). Dissertação de Mestrado. Instituto de Biociências, Universidade de São Paulo. São Paulo.

ASSUMPÇÃO, C.T., LEITÃO FILHO, H.F. \& CESAR, O. 1982. Descrição das matas da Fazenda Barreiro Rico, Estado de São Paulo. Revista Brasil. Bot. 5: 53-66.

BACKES, A. 1999. Condicionamento climático e distribuição geográfica de Araucaria angustifolia (Bertol.) Kuntze no Brasil - II. Pesquisas Botânica 49: 31-51.

BAITELlO, J.B. \& AGUIAR, O.T. 1982. Flora arbórea da Serra da Cantarcira (São Paulo). Silvic. S.Paulo 16A(1): 582 - 590.

BAITEllo, J.B., AGUiAR, O.T., ROCHA, F.T., PASTORE, J.A. \& ESTEVES, R. 1992. Florística e fitossociologia do estrato arbóreo de um trecho da Serra da Cantareira (Núcleo Pinheirinho) - SP. Revista Inst. Florestal 4(1): 291 - 297. 
BAITELlO, J.B., AGUIAR, O.T., ROCHA, F.T., PASTORE, J.A. \& ESTEVES, R. 1993. Estrutura fitossociológica da vegctação arbórca da Scrra da Cantarcira (SP) - Núcleo Pinhcirinho. Revista Inst. Florestal 5(2): 133-161.

BAITELLO, J.B., PASTORE, J.A., AGUIAR, O.T., SÉRIO, F.C., SILVA, C.E.F. 1988. A vegetação arbórca do Parque Estadual do Morro do Diabo, municipio de Tcodoro Sampaio, Estado de São Paulo. Acta Bot. Brasil. 2 (supl.): 221-230.

BARROS, F., MELO, M.M.R.F., CHIEA, S.A.C., KIRIZAWA, M., WANDERLEY, M.G.L. \& JUNG-MENDAÇOLLI, S.L. 1991. Caracterização geral da vegetação $\mathrm{c}$ listagem das espécics ocorrentes. In M.M.R.F. Mclo et al. (cds) Flora Fanerogâmica da Ilha do Cardoso. Instituto de Botânica. São Paulo, vol 1, p. 1-184.

BAZZAZ, F.A. 1983. Characteristics of population in relation to disturbance in natural and man-modified ecosystems. In H.A. Mooney \& M. Godron (cds) Disturbance and ecosystem. Springer-Verlag. New York, p. 259277.

BERTONI, J.E.A. \& MARTINS, F.R. 1987. Composição florística de uma floresta ripária na Reserva Estadual de Porto Ferreira, SP. Acta Bot. Brasil. 1(1): 17-26.

CATHARINO, E.L.M. 1989. Estudos fisionômico-floristicos e fitossociológicos em matas residuais secundárias no municipio de Piracicaba, SP. Dissertação de Mestrado. Universidade Estadual de Campinas. Campinas.

CAVASSAN, O., CESAR, O. \& MARTINS, F.R. 1984. Fitossociologia da vegetação arbórea da Reserva Estadual de Bauru, Estado de São Paulo. Revista Brasil. Bot. 7(2): 91-106.

CESAR, O. \& LEITÃO FILHO, H.F. 1990. Estudo florístico quantitativo de mata mesófila semidecídua na Fazenda Barreiro Rico, municipio de Anhembi, SP. Revista Brasil. Biol. 50(1): 133-147.

COSTA, L.G.S. \& MANTOVANI, W. 1995. Flora arbustivo-arbórea de trecho de mata mesófila semidccídua, na Estação Ecológica de Ibicatu, Piracicaba, SP. Hoehnea 22(1/2): 47-59.

CUSTÓDIO FILHO, A. 1989. Flora da Estação Biológica de Boracćia Listagem de Espécies. Revista Inst. Florestal 1(1): 161-199.

CUSTÓDIO FILHO, A.; NEGREIROS, O.C.; DIAS, A.C.; FRANCO, G.A.D.C. 1992. Composição florística do estrato arbórco do Parque Estadual de Carlos Botelho, SP. Revista Inst. Florestal 4: 184-191.

FURLAN, A. 1996. A Tribo Pisonieae (Nyctaginaceae) no Brasil. Tese de Doutorado. Instituto de Biociências, Universidade de São Paulo. São Paulo.

GANDOLFI, S. 1991. Estudo floristico e fitossociológico de uma floresta residual na área do Aeroporto Internacional de São Paulo, municipio de Guarulhos, SP. Dissertação de Mestrado. Universidade Estadual de Campinas. Campinas.

GARCIA, R.J.F. 1995. Composição florística dos estratos arbóreo e arbustivo da mata do Parque Santo Dias (São Paulo - SP, Brasil). Dissertação de Mestrado. Instituto de Biociências, Universidade de São Paulo. São Paulo.

GIBBS, P.E. \& LEITÃO FILHO, H.F. 1978. Floristic composition of an area of gallery forest near Mogi Guaçu, State of São Paulo. S.E. Brazil. Revista Brasil. Bot. 1: 151-156.

GOMES, E.P.C. 1992. Fitossociologia do componente arbóreo de um trecho de mata em São Paulo, SP. Disscrtação de Mestrado. Instituto de Biociências, Universidade de São Paulo. São Paulo.

HENDERSON, A., GALEANO, G. \& BERNAL, R. 1995. Field guide to the Palms of the Americas. Princeton Universty Press. Princeton.

HUECK, K. 1956. Mapa fitogeográfico do Estado de São Paulo. Bol. Paul. Geogr. 22: 19-25.

IBGE. 1993. Mapa de Vegetação do Brasil. ed. 2, escala 1:5.000.000. Fundação Instituto Brasileiro de Gcografia c Estatística. Rio de Janciro.

JANZEN, D. 1980. Ecologia Vegetal nos Trópicos. E.P.U., Edusp. São Paulo.

JOLY, A.B. 1950. Estudo fitogeográfico dos campos de Butantã (São Paulo). Bol. Fac. Filos. Univ. São Paulo, Bot. 8: 5-68.

KUHLMANN, M. \& KÜHN, E. 1947. A flora do distrito de Ibiti (ex-Monte Alegre), municipio de Amparo. Instituto de Botânica. São Paulo.
LEITÃO FILHO, H.F. 1992a. A flora arbórea da Scrra do Japi. In Morellato, L.P.C.(org.) História Natural da Serra do Japi: ecologia e preservaçào de uma área florestal no Sudeste do Brasil. Ed. UNICAMP, FAPESP. Campinas, p. 40-63.

LEITÃO FILHO, H.F. 1992b. A flora arbórca dos cerrados do Estado de São Paulo. Hoehnea 19(1/2):151-163.

LEITÃO FILHO, H.F. (coord.) 1993. Ecologia da mata atlântica em Cubatão (SP). Ed. UNESP, Ed. UNICAMP. São Paulo/Campinas.

MANTOVANI, W. 1992. A vegetação sobre a restinga em Caraguatatuba, SP. Revista Inst. Florestal 4(1): 139-144.

MANTOVANI, W. 1993. Estrutura e dinâmica da floresta atlântica na Juréia, Iguape - SP. Tesc dc Livre-Docência. Instituto de Biociências, Universidade de São Paulo. São Paulo.

MARTINS, F.R. 1991. Estrutura de uma floresta mesófila. Ed. UNICAMP. Campinas.

MATTHES, L.A.F. 1980. Composição floristica, estrutura e fenologia de uma floresta residual do planalto paulista: Bosque dos Jequitibás (Campinas, SP). Disscrtação de Mestrado. Universidade Estadual de Campinas. Campinas.

MEIRA NETO, J.A.; BERNACCI, L.C.; GROMBONE, M.T.; TAMASHIRO, J.Y. \& LEITÃO FILHO, H.F. 1989. Composição florística da floresta semidecídua de altitude do Parque Municipal da Grota Funda (Atibaia - Estado de São Paulo). Acta Bot. Brasil. 3(2): 51-74.

MELHEM, T.S., GIULIETTI, A.M., FORERO, E., BARROSO, G.M., SILVESTRE, M.S.F., JUNG, S.L., MAKINO, H., MELO, M.M.R.F., CHIEA, S.C., WANDERLEY, M.G.L., KIRIZAWA, M. \& MUNIZ, C. 1981. Plancjamento para a elaboração da "Flora Fanerogâmica da Reserva do Parque Estadual das Fontes do Ipiranga (São Paulo, Brasil)". Hoehnea 9: 63-74.

MELO, M.M.R.F. \& MANTOVANI, W. 1994. Composição floristica c estrutura de trecho de mata atlântica de encosta, na Ilha do Cardoso (Cananćia, SP, Brasil). Bol. Inst. Bot. (São Paulo) 9: 107-158.

MENCACCI, P.C. \& SCHLITTLER, F.H.M. 1992. Fitossociologia da vegetação arbórea da mata ciliar de Ribeirão Claro, município de Rio Claro - SP. Revista Inst. Florestal 4(1): 245-251.

MUELLER-DOMBOIS, D. \& ELLEMBERG, H. 1974. Aims and methods of vegetation ecology. John Wiley \& Sons. New York.

NASTRI, V.D.F.; CATHARINO, E.L.M.; ROSSI, L.; BARBOSA, L.M.; PIRRÉ, E.; BEDINELLI, C.; ASPERTI, L.M.; DORTA, R.O.; COSTA, M.P. 1992. Estudos fitossociológicos em uma área do Instituto de Botânica de São Paulo utilizados em programas de Educação Ambiental. Revista Inst. Florestal 4(1): 219-225.

OLIVEIRA FILHO, A.T. \& RATTER, J.A. 1995. A study of the origin of central Brazilian forests by the analysis of plant species distribution patterns. Edinb. J. Bot. 52(2): 141- 194.

ORTEGA, V.R.\& ENGEL, V.L. 1992. Conservação da biodiversidade $\mathrm{cm}$ remanescentes de mata atlântica na região de Botucatu, SP. Revista Inst. Florestal 4(3): 839-852.

PAGANO, S.N. \& LEITÃO FILHO, H.F. 1987. Composição florística do estrato arbóreo de mata mesófila semidecídua no município de Rio Claro (Estado de São Paulo). Revista Bras. Bot. 10(1): 37 - 48.

PASTORE, J.A., AGUIAR, O.T., ESTEVES, R. \& SILVA, C.A.F. 1992. Flora arbóreo-arbustiva do Parque Chico Mendes, Município de São Bernardo do Campo (SP). Revista Inst. Florestal 4(1): 269-273.

PIJL, L. van der 1969. Principles of dispersal in higher plants. SpringerVerlag. Berlin.

PREFEITURA DO MUNICÍPIO DE SÃO PAULO 1994. Relatório final do GT de detalhamento da carta geotécnica do municipio de São Paulo. Secretaria Municipal do Planejamento. São Paulo.

RADFORD, A.E., DICKSON, W.C., MASSEY, J.R. \& BELL, C.R. 1974. Vascular Plant Systematics. Harper \& Row Publ. New York.

RAMOS NETO, M.B. 1993. Análise florística e estrutural de duas florestas sobre a restinga, Iguape, São Paulo. Dissertação de Mestrado. Instituto de Biociências, Universidade de São Paulo. São Paulo.

REITZ, R. \& KLEIN, R.M. 1966. Araucariáccas. In R. Reitz (ed.) Flora Ilustrada Catarinense. Herbário Barbosa Rodrigues. Itajai. 
ROBIM, M.J., PASTORE, J.A., AGUIAR, O.T. \& BAITELLO, J.B. 1990. Flora arbórco arbustiva $\mathrm{c}$ herbácea do Parque Estadual de Campos do Jordāo (SP). Revista Inst. Florestal 2(1): 31-53.

ROIZMAN, L.G. 1993. Fitossociologia e dinâmica do banco de sementes de populações arbóreas de floresta secundária em São Paulo, SP. Disscrtação de Mestrado. Instituto de Biociências, Universidade de São Paulo. São Paulo.

ROSSI, L. 1994. A flora arbóreo-arbustiva da mata da Reserva da Cidade Universitária "Armando de Salles Oliveira" (São Paulo, Brasil). Bol. Inst. Bot. (São Paulo) 9: 1-105.

SALIS, S.M., SHEPHERD, G.J. \& JOLY, C.A. 1995. Floristic comparision of mesophitic semideciduous forests of the interior of the state of São Paulo, Southeast Brazil. Vegetatio 119: 135-164.

SILVA, A.F. 1989. Composição floristica e estrutura fitossociológica do estrato arbóreo da Reserva Florestal Professor Augusto Ruschi, São José dos Campos - SP. Tese de Doutorado. Universidade Estadual de Campinas. Campinas.

SILVA, A.F. \& LEITÃO FILHO, H.F. 1982. Composição florística c estrutura de um trecho de Mata Atlântica de encosta no Município de Ubatuba (São Paulo, Brasil). Revista Brasil. Bot. 5(1/2): 43-52.

SILVA, A.F. \& SHEPHERD, G.J. 1986. Comparações floristicas entrc algumas matas brasileiras utilizando análises de agrupamento. Revista Brasil. Bot. 9: 81-86.
STRUFFALDI-DE-VUONO, Y. 1985. Fitossociologia do estrato arbóreo da floresta da Reserva Biológica do Instituto de Botânica (São Paulo, $S P)$. Tesc de Doutorado. Instituto de Biociências, Universidade de São Paulo. São Paulo.

TABARELLI, M., VILLANI, J.P. \& MANTOVANI, W. 1993. Aspectos da succssão sccundária $\mathrm{cm}$ trecho da floresta atlântica no Parque Estadual da Scrra do Mar, SP. Revista Inst. Florestal 5(1): 99-112.

TAKAHASHI, E., BARNABÉ, H.R., CHANG, J., LAGANÁ, M.S.A.F.L. \& CRUZ, V.I.M.S. 1993. Projeto: Parque Santo Dias. In Secretaria Municipal do Verde c do Mcio Ambientc A Questão Ambiental Urbana: Cidade de São Paulo. PMSP-SVMA. São Paulo.

TAYLOR, C.M. \& LORENCE, D.H. 1993. On the status of Randia armata (Sw.) DC. (Rubiaccac: Gardeniac). Taxon 42: 865-867.

VELOSO, H.P., RANGEL FILHO, A.L.R. \& LIMA, J.C.A. 1991. Classificação da vegetação brasileira, adaptada a um sistema universal. IBGE. Rio de Janciro.

VIEIRA, M.G.L., MORAES, J.L., BERTONI, J.E.A., MARTINS, F.R. \& ZANDARIN, M.A. 1989. Composição florística e estrutura fitossociológica da vegetação arbórea do Parque Estadual de Vaçununga, Santa Rita do Passa Quatro (SP). II - Gleba Capetinga Ocstc. Revista Inst. Florestal 1(1): 135-159. 